\title{
Pengaruh Promosi, Atribut Toko (Store Attributes), dan Inovasi Produk Terhadap Keputusan Pembelian Ulang pada Nick Coffe di Kota Bengkulu
}

\author{
Munifah Khomilah ${ }^{1}$ \\ ${ }^{1}$ Program Studi Manajemen UM. Bengkulu \\ Hasil Penelitian FEB UM. Bengkulu Tahun 2020
}

\begin{abstract}
ABSTRAK
Penelitian ini bertujuan untuk mengetahui pengaruh Promosi, Atribut Toko (Store Attributes), dan Inovasi Produk Terhadap Keputusan Pembelian Ulang pada Nick Coffe di Kota bengkulu. Penelitian ini merupakan penelitian kuantitatif dengan sampel berjumlah 96 orang responden, menggunakan teknik accidental sampling. Teknik pengumpulan data dengan menggunakan observasi dan kuesioner. Teknik analisis data dengan menggunakan uji asumsi klasik, regresi linier berganda, Koefisien Determinasi $\left(\mathrm{R}^{2}\right)$ dan uji hipotesis. Hasil penelitian ini dapat dilihat dari uji regresi linier berganda dengan menggunakan SPSS yaitu $Y=2.063+0.192 \mathrm{X}_{1}+0.036 \mathrm{X}_{2}+0.713 \mathrm{X}_{3}$. Dari hasil uji hipotesis bahwa Promosi $\left(\mathrm{X}_{1}\right)$ berpengaruh positif terhadap Keputusan Pembelian Ulang pada Nick Coffe di Kota bengkulu, dengan hasil uji $\mathrm{T}$ menunjukkan nilai signifikansi $0.000<0.05$, Atribut Toko $\left(\mathrm{X}_{2}\right)$ berpengaruh positif terhadap Keputusan Pembelian Ulang pada Nick Coffe di Kota bengkulu, dengan hasil uji $\mathrm{T}$ menunjukkan nilai signifikansi $0.037<0.05$, Inovasi Produk $\left(\mathrm{X}_{3}\right)$ berpengaruh positif terhadap Keputusan Pembelian Ulang pada Nick Coffe di Kota bengkulu, dengan hasil uji $\mathrm{T}$ menunjukkan nilai signifikansi $0.000<0.05$, Pengujian hipotesis uji $\mathrm{T}$ dan uji $\mathrm{F}$ menunjukkan bahwa Promosi, Atribut Toko (Store Attributes), dan Inovasi Produk berpengaruh signifikan terhadap Keputusan Pembelian Ulang dengan tingkat signifikansi $<0,05$. Ini berarti Ho ditolak Ha diterima. Dengan kata lain Promosi, Atribut Toko (Store Attributes), dan Inovasi Produk berpengaruh signifikan baik secara parsial maupun simultan Terhadap Keputusan Pembelian Ulang pada Pelanggan Nick Coffe. Hal ini dibuktikan dengan uji f menunjukkan nilai signifikasi sebesar $0.000<0.05$.
\end{abstract}

Kata Kunci : Promosi, Atribut Toko(Store Attributes), dan Inovasi Produk dan Keputusan Pembelian Ulang 
The Effect Of Promotion, Store Attributes, and Product Innovation On

Repurchase Decisions on Nick Coffe In Bengkulu City

\title{
Munifah Khomilah
}

\begin{abstract}
This study aims to determine the effects of Promotions, Store Attributes, and Product Innovations on Repurchase Decisions on Nick Coffe in Bengkulu City. This research is a quantitative study with a sample of 96 respondents, using accidental sampling techniques. collection techniques using observation and questionnaires. Data analysis techniques using the classic assumption test, multiple linear regression, coefficient of determination (R2) and hypothesis testing. The results of this study can be seen from the multiple linear regression tests using SPSS namely $\mathrm{Y}=2.063+0.192 \mathrm{X} 1+0.036 \mathrm{X} 2+0.713 \mathrm{X} 3$. From the results of hypothesis testing that Promotion (X1) has a positive effect on Repurchase Decisions on Nick Coffe in Bengkulu City, with $\mathrm{T}$ test results showing a significance value of $0.000<0.05$, Store Attribute (X2) has a positive effect on Repurchase Decisions on Nick Coffe in Bengkulu City, with $\mathrm{T}$ test results showing a significance value of $0.037<0.05$, Product Innovation (X3) has a positive effect on Repurchase Decisions on Nick Coffe in Bengkulu City, with $\mathrm{T}$ test results showing a significance value of $0,000<0.05$, Hypothesis testing of the $\mathrm{T}$ test and $\mathrm{F}$ test shows that Promotion, Store Attributes, and Product Innovation have a significant effect on Repurchase Decisions with a significance level $<0.05$. This means that Ho was refused Ha was accepted. In other words Promotions, Store Attributes, and Product Innovations have a significant effect both partially and simultaneously on Repurchase Decisions on Nick Coffe Customers. This is evidenced by the $\mathrm{F}$ test showing a significance value of $0.000<0.05$.
\end{abstract}

Keywords: Promotion, Store Attributes, and Product Innovation and Repurchase Decisions 


\section{BAB I}

\section{PENDAHULUAN}

\subsection{Latar Belakang}

Perkembangan dalam dunia bisnis sudah semakin cepat dan persaingannya semakin ketat, hal ini mengharuskan setiap pelaku usaha mampu untuk memanfaatkan semua potensi dan peluang yang dimilikinya, mengatasi kelemahan dan ancaman yang dihadapinya, serta memiliki keunggulan kompentitif, dan yang terpenting adalah menjalin serta meningkatkan hubungan dengan pelanggan. Para pelaku usaha harus berusaha lebih keras agar tetap dapat bertahan.

Perkembangan pada era globalisasi ini, membuat dunia usaha memiliki pesaing yang banyak, dengan begitu mereka akan membuktikan apa yang menjadi ciri khusus penjualan mereka. Seperti yang kita ketahui, terdapat banyak sekali Cafe atau sejenis tempat untuk nongkrong. Dimana biasanya mereka hanya sekedar untuk minum kopi, bermain games bersama dan mengobrol. Begitu pula saat ini di kota Bengkulu, Cafe atau pun usaha kuliner sedang menjadi trend yang sudah mulai banyak berdiri. Oleh karena itu para pengusaha bersaing satu dengan yang lain Membuat sesuatu yang berbeda untuk menarik minat konsumen dengan jenis produk yang serupa.

Untuk itu, pengusaha harus pintar melihat serta menentukan strategi yang tepat untuk memenangkan persaingan tersebut. Salah satu tujuan mendirikan 
usaha adalah mendapatkan konsumen sebanyak-banyaknya untuk memperoleh keuntungan yang sebesar-besarnya, oleh karena itu para produsen harus pintar dalam melihat peluang usaha yang bisa dijadikan bisnis.

Maka dari itu kita harus bisa membuat konsumen puas, dengan begitu konsumen tersebut akan melakukan pembelian ulang. Menurut Schiffman dan Kanuk dalam Long-Yi Lin dan Yeun-Wen Chen,(2009) "Keputusan pembelian ulang sendiri adalah ketika konsumen memutuskan untuk membeli kembali sebuah produk yang bisa saja didasarkan pada keinginan konsumen, bahwasannya produk tersebut memenuhi apa yang diinginkan mereka”. Pengukuran keputusan pembelian ulang terdiri dari 2 indikator pengukuran yaitu pembelian kembali produk yang sama di masa datang, dan jumlah pembelian.

Agar terjadinya pembelian ulang, biasanya konsumen akan melihat sebuah promosi yang dimiliki oleh Cafe tersebut. Menurut Boone dan Kurtz (2002 : 129) "promosi adalah proses menginformasikan, membujuk, dan mempengaruhi suatu keputusan pembelian”. Dengan adanya promosi perusahaan bertujuan untuk dapat membujuk konsumen untuk melakukan pembelian atas produk yang dipasarkan. Tujuan utama promosi adalah memberi informasi, menarik perhatian konsumen dan selanjutnya memberi pengaruh agar terjadi pembelian. Strategi promosi yang kreatif dan segar dapat menarik minat konsumen untuk melihat barang atau jasa yang ditawarkan dan kemudian melakukan pembelian. Perusahaan yang dapat melakukan promosi dengan baik juga akan meningkatkan penjualan perusahaan. 
Seperti halnya yang dilakukan oleh Nick Coffe, Promosi juga menjadi salah satu cara dimana mereka menarik minat konsumen dan mempertahankan persaingannya dengan Cafe lain. Promosi yang dilakukan oleh Nick Coffe bertujuan untuk membuat para konsumen menjadi tertarik dan menjadikan Nick Coffe sebagai pilihan cafe yang akan mereka tuju baik sekedar untuk nongkrong, bercengkrama dengan teman, atau pun menikmati kopi dan berbagai menu lain yang ada di sana. Tetapi promosi yang dilakukan Nick Coffe hanya di awal pada saat opening, setelah itu Nick Coffe jarang atau bahkan tidak pernah lagi memberikan diskon, atau pun potongan harga terhadap konsumen.

Kondisi atribut toko (Store Attributes) merupakan hal yang sangat mempengaruhi proses pemilihan toko dan menarik keputusan pembelian ulang konsumen. Store Attributes memiliki peran penting karena lingkungan (seluruh fisik sekitar maupun benda-benda yang memiliki bentuk) dapat memberikan pengaruh pada pembelian ulang. Konsumen mencari tempat yang dianggap menarik dan juga dapat menyediakan pengalaman yang menyenangkan. Kesan terhadap toko dapat dibentuk pada saat konsumen memasuki atau baru saja memasuki area fasilitas toko.

Dalam memilih toko konsumen memiliki keriteria evaluasi diantaranya adalah faktor kenyamanan, pelayanan, kelengkapan produk, dan lain sebagainya hal tersebut menjadikan faktor yang sangat penting dan harus diperhatikan produsen karena akan menjadi bahan perbandingan bagi konsumen untuk memilih toko mana yang akan didatangi kembali oleh konsumen. 
Atribut toko yang di miliki oleh Nick Coffe menjadi daya tarik tersendiri bagi konsumen untuk datang kembali, dimana pelayanan yang di berikan pegawai di Nick Coffe sudah bisa memuaskan konsumen, fasilitas yang di tawarkan seperti Games Uno, Acoustic bagi konsumen yang ingin bernyanyi atau pun sekedar mendengarkan, dll menjadi faktor pendukung konsumen untuk melakukan pembelian ber ulang. Tetapi banyak konsumen yang masih mengeluh masalah keamanan di area parkiran khususnya bagian motor, karna masih ada kemungkinan untuk kehilangan helm yang mereka bawa, padahal disana sudah ada orang yang menjadi juru parkir. Keadaan Cafe Nick Coffe yang $80 \%$ adalah outdoor (di luar ruangan), dan mayoritas konsumen yang berdatangan di malam hari.

Menurut Prokosa (2013: 45) mengatakan bahwa "inovasi adalah suatu mekanisme perusahaan untuk beradaptasi dengan lingkungan yang dinamis”. Oleh sebab itu dituntut untuk mampu menciptakan pemikiran-pemikiran baru, gagasangagasan baru dengan menawarkan produk yang inovatif serta peningkatan pelayanan yang dapat memuaskan pelanggan. Dua konsep inovasi yang diajukannya adalah keinovativan dan capacitas berinovasi. Keinovasian adalah pikiran tentang keterbukaan untuk gagasan baru sebagai aspek budaya perusahaan, sedangkan kapasitas untuk berinovasi adalah kemampuan perusahaan untuk menggunakan atau menerapkan gagasan, proses/produk baru secara berhasil.

Sehingga dapat diartikan bahwa inovasi produk merupakan suatu usaha yang dijalankan perusahaan untuk menciptakan produk baru yang bertujuan untuk 
menyesuaikan dengan selera konsumen dan dapat meningkatkan penjualan. Bertambah banyaknya jumlah barang yang ditawarkan kepada konsumen dan ditunjang dengan arus informasi tentang produk, menyebabkan semakin selektif dalam membeli suatu barang, baik dalam kualitas, desain corak, warna maupun harganya. Nick coffe juga berusaha untuk membuat produk yang baru dari yang lain, berusaha untuk selalu memperbaiki kualitas yang mereka miliki agar konsumen merasa puas dan ingin kembali melakukan pembelian ulang, memperbanyak produk yang mereka kembangkan menjadi menu - menu yang baru, ada pun mereka juga mengikuti perkembangan zaman yang saat ini diminati oleh konsumen atau biasa disebut dengan kekinian.

kebanyakan Konsumen menjadikan Promosi, Atribut Toko (Store Attributes), dan inovasi produk sebagai acuan mereka untuk melakukan pembelian ulang di Nick coffe, maka dari itu keputusan pembelian ulang berpengaruh terhadap naik turunnya omset penjualan. Hal ini dapat dilihat dari tabel data penjualan berikut ini.

Tabel 1.1

Data penjualan Nick Coffe pada bulan Agustus sampai Oktober 2019

\begin{tabular}{|c|l|c|}
\hline No & \multicolumn{1}{|c|}{ Bulan } & Pendapatam/Rp \\
\hline 1. & Agustus & $132.000 .000,00$ \\
\hline 2. & September & $130.000 .000,00$ \\
\hline 3. & Oktober & $133.000 .000,00$ \\
\hline \multicolumn{2}{|c|}{ Total } & $\mathbf{3 9 5 . 0 0 0 . 0 0 0 , 0 0}$ \\
\hline
\end{tabular}

Sumber : Nick Coffe Bengkulu 2019 
Tabel 1.1 merupakan hasil data pra penelitian, penelitian menggunakan data penjualan bulan Agustus sampai Oktober di Nick Coffe Bengkulu. Dari data tersebut menunjukkan bahwa penjualan mengalami ketidak stabilan setiap bulannya. Hal ini menunjukan kurang optimalnya Promosi, Atribut Toko (Store Attribut), dan inovasi produk yang berdampak kepada keputusan pembelian ulang.

Nick Coffe merupakan salah satu cafe yang ada di Kota Bengkulu yang beralamat di Rumah Makan Pringgading, Jalan Ciliwung Bawah, No 33 Kota Bengkulu, cafe ini dibuka mulai dari jam 10.00 - 23.00. Pelayanan yang diberikan kepada pelanggan juga sangat baik terlihat dari keramahan karyawan dalam menyapa pelanggan yang datang ke cafe tersebut, Nick Coffe juga menyediakan alat Accoustic untuk para pelanggan yang ingin mengekspresikan diri atau menghibur pelanggan yang lain.

Berdasarkan latar belakang yang diuraikan tersebut, penulis tertarik untuk mengambil judul "Pengaruh Promosi, Atribut Toko (Store Attributes) Dan Inovasi Produk Terhadap keputusan Pembelian Ulang (Pada Nick Coffe Di Kota Bengkulu)"

\subsection{Rumusan Masalah}

Berdasarkan uraian di atas, masalah yang diteliti dapat dirumuskan sebagai berikut :

1. Apakah Promosi Berpengaruh Terhadap keputusan Pembelian Ulang Di Nick Coffe ?

2. Apakah Atribut Toko (Store Attributes ) Berpengaruh Terhadap keputusan Pembelain Ulang Di Nick Coffe ? 
3. Apakah Inovasi Produk Berpengaruh Terhadap keputusan Pembelain Ulang Di Nick Coffe ?

4. Apakah Promosi, Atribut Toko, dan Inovasi Produk Berpengaruh Terhadap keputusan Pembelian Ulang Di Nick Coffe ?

\subsection{Batasan Masalah}

Untuk permasalahan dalam penelitian ini tidak meluas dan menyimpang dari tujuan utamanya, Maka perlu dilakukan pembatasan masalah. Dalam penelitian ini permasalahan dibatasi pada masalah, Promosi (X1), Atribut toko (X2), Inovasi Produk (X3), dan keputusan Pembelian Ulang (Y).

\subsection{Tujuan Penelitian}

\subsubsection{Tujuan Umum}

Untuk mengetahui pengaruh Promosi, Atribut Toko (Store Attributes), dan Inovasi Produk terhadap keputusan Pembelian Ulang di Nick Coffe Bengkulu.

\subsubsection{Tujuan Khusus}

1. Untuk Mengetahui Pengaruh Promosi Terhadap keputusan Pembelian Ulang Di Nick Coffe.

2. Untuk Mengetahui Pengaruh Atribut Toko (Store Attribute) Terhadap keputusan Pembelian Ulang Di Nick Coffe.

3. Untuk Mengetahui Pengaruh Inovasi Produk Terhadap keputusan Pemblian Ulang Di Nick Coffe.

4. Untuk Mengetahui Pengaruh Promosi, Atribut Toko (Store Attributes), dan Inovasi Produk Terhadap keputusan Pembelian Ulang Di Nick Coffe. 


\subsection{Manfaat penelitian}

1. Bagi Penulis, untuk memperoleh tambahan wawasan dan pengetahuan tentang pentingya mengetahui Pengaruh Promosi, Atribut Toko (Store Attributes) dan Inovasi Produk terhadap keputusan Pembelian Ulang di Nick Coffe dan untuk menerapkan ilmu teoritis yang diperoleh semasa dibangku kuliah.

2. Bagi Perusahaan, dapat memberikan gambaran dan informasi yang berguna bagi perusahaan dalam melakukan kebijakan dan strategi pemasaran yang berkaitan dengan Pengaruh Promosi, Atribut Toko (Store Attributes) dan Inovasi Produk terhadap keputusan Pembelian Ulang.

3. Bagi Peneliti Lain, sebagai bahan referensi dan informasi bagi peneliti lain yang ingin melakukan penelitian lebih lanjut trutama yang berhubungan dengan Pengaruh Promosi, Atribut Toko (Store Attributes) dan Inovasi Produk terhadap keputusan Pembelian Ulang. 


\section{BAB II}

\section{STUDI PUSTAKA}

\subsection{Landasan Teori}

Untuk mendukung pembuatan laporan ini, maka perlu dikemukakan halhal atau teori-teori yang berkaitan dengan permasalahan dan ruang lingkup pembahasan sebagai landasan dalam pembuatan laporan ini.

\subsubsection{Keputusan Pembelian Ulang}

\section{a. Pengertian Keputusan Pembelian Ulang}

Pengertian dari "keputusan pembelian ulang sendiri yaitu pertimbangan individu terkait dengan pembelian ulang suatu produk dari suatu perusahaan yang dipengaruhi oleh kondisi lingkungan sekitarnya" (Hellier et al., (2003), Spais dan Vasileiou, (2006), Atchariyachanvanich et al., (2006), dalam Sylvi (2009), dari definisi diatas dapat disimpulkan jika kondisi suatu lingkungan tersebut baik, maka potensi terjadinya pembelian ulang juga akan semakin tinggi. Jika kondisi lingkungan yang ada buruk, maka potensi terjadinya pembelian ulang pun juga rendah.

Pengertian pembelian ulang (Repeat Purchase) menurut Peter/Olsen dalam Novantiano (2007: 24) adalah "Kegiatan pembelian yang dilakukan lebih dari satu kali atau beberapa kali”. Jadi pembelian ulang adalah suatu proses membeli barang atau jasa untuk kesekian kalinya, setelah melakukan proses membeli

sebelumnya. Keputusan pembelian ulang merupakan pengembangan dari teori keputusan pembelian konsumen. Keputusan pembelian ulang tercipta setelah konsumen melakukan serangkaian proses pembelian konsumen, yaitu: pengenalan 
masalah, pencarian informasi, evaluasi alternatif, keputusan pembelian dan perilakupasca pembelian. Menurut Simamora (2003: 51) dalam Yuda Melisa (2012) "Yang di pertimbangkan konsumen dalam melakukan pembelian ulang hanya dua, yaitu:faktor harga dan bukan harga". Faktor bukan harga terdiri dari faktor produk dan non produk. Apabila seseorang sudah melakukan pembelian terhadap suatu produk dan melakukan pembelian ulang terhadap produk tersebut, maka perilaku yang mungkin ditujukan ada dua menurut simamora (2003: 28) yaitu; "pemecahan masalah berulang dan perilaku kebiasan".

Menurut Chang \& Wildt, (1994); Petrick, Backman \& Bixler,(1999); Woodruff, (1997) "tujuan dari pembelian ulang yaitu merupakan suatu tingkat motivasional seorang konsumen untuk mengulangi perilaku pembelian suatu produk, yang salah satunya ditunjukkan dengan penggunaan brand suatu produk secara berkelanjutan” (Johanna, 2006). Ketika konsumen memiliki tujuan tertentu dalam pembelian ulang terhadap suatu produk yang dengan brand tertentu, maka secara tidak langsung konsumen tersebut telah mempunyai perilaku loyal dan rasa puas terhadap produk dengan brand tersebut. Sehingga tanpa disadari secara tidak langsung pembelian ulang telah mengandung unsur loyal terhadap brand dari suatu produk.

Pada dasarnya keputusan pembelian ulang sendiri terjadi dikarenakan adanya faktor kepuasan konsumen, yang dimana seorang konsumen merasakan manfaat dan mendapatkan kepuasan dari pengonsumsian produk/jasa sehingga berniat untuk melakukan pengonsumsian kembali terhadap produk tersebut di lain waktu. Keputusan pembelian ulang pada dasarnya merupakan bagian dari 
loyalitas merek yang dimana didefinisikan menurut Mowen \& Minor (1998), dalam Johanna (2006), “yaitu sebagai kondisi dimana konsumen memiliki perilaku yang positif terhadap suatu merek, dan memiliki komitmen pada merek tersebut, serta bermaksud meneruskan pembeliannya di masa yang akan datang". Menurut Kotler dan Amstrong (2001: 83) "lokasi pengecer adalah kunci bagi kemampuannya menarik pelanggan". Pada lokasi yang tepat, sebuah gerai akan lebih sukses dibanding yang lainnya, meskipun keduanya menjual produk yang sama, oleh pramuniaga yang sama banyak dan terampil, dan sama-sama punya seting yang bagus.

Dalam menentukan lokasi suatu perusahaan ritel, menurut Berman dan Evans (2007: 305) “diperlukan sebuah Cheklis Lokasi dan Posisi yang terdiri dari: Lalu Lintas Pejalan Kaki, Lalu Lintas Kendaraan, Fasilitas Parkir, Transportasi, Komposisi Toko, Situs Spesifik, Persyaratan Bangunan”. Utami (2005: 114) juga menjelaskan bahwa "perusahaan ritel memiliki tiga jenis dasar pilihan lokasi, yaitu pusat perbelanjaan, lokasi di kota atau bertempat di tengah kota, maupun kota kecil dan lokasi bebas".

Berkaitan dengan uraian di atas, dapat disimpulkan bahwa Keputusan Pembelian Ulang adalah perasaan puas seseorang dengan begitu ketika seseorang merasa puas akan terjadinya pembelian berulang.

\section{b. Indikator Keputusan Pembelian Ulang}

Unsur penting dalam perilaku konsumen adalah proses pengambilan keputusan dalam pembelian. Pembelian merupakan suatu proses di mana kegiaatan pembelian nyata hanyalah satu tahap dari keseluruhan proses pembelian 
dikonsumsi. Perilaku konsumen akan sangat menentukan proses pengambilan keputusan dalam pembelian. Proses pembelian yang dilakukan oleh konsumen ada lima tahap menurut Kotler dan Amstrong (2004) antara lain:

1. Pengenalan kebutuhan

Tahap pertama proses keputusan pembelian yaitu konsumen mengenali adanya masalah atau kebutuhan. Pembeli merasa ada suatu perbedaan antara keadaan yang nyata dengan keadaan yang diinginkan.

2. Pencarian informasi

Tahap ini merupakan tahap dimana konsumen tergerak untuk mencari informasi tambahan. Konsumen mungkin sekedar meningkatkan perhatian informasi tambahan. Konsumen mungkin sekedar meningkatkan perhatian atau mungkin pula mencari informasi secara aktif.

3. Evaluasi alternatif

Tahap berikutnya adalah proses keputusan pembelian dimana konsumen menggunakan informasi untuk mengevaluasi berbagai merek alternatif di dalam serangkaian pilihan.

4. Keputusan pembelian

Proses dimana konsumen benar-benar membeli. Pada umumnya keputusan membeli konsumen adalah membeli merek yang paling disukai.

5. Perilaku setelah pembelian 
Setelah membeli produk, konsumen akan melakukan tindakan lebih lanjut berdasarkan pada kepuasan dan ketidakpuasan mereka akan produk tersebut.

\section{c. Proses Pengambilan Keputusan Pembelian :}

1. Pengenalan masalah kebutuhan, proses ini dimulai pada saat konsumen menyadari adanya masalah kebutuhan. Konsumen harus menyadari terdapat perbedaan antara kondisi yang diinginkan dengan kondisi yang sebenarnya terjadi. Kebutuhan ini disebabkan rangsangan internal yang berasal dari dalam diri konsumen.

2. Pencarian informasi, pada tahap ini seseorang konsumen yang mulai timbul minatnya akan terdorong mencari informasi yang lebih banyak. Pencarian informasi mulai dilakukan ketika konsumen memandang bahwa kebutuhan tersebut dapat dipenuhi dengan membeli dan mengkonsumsi suatu produk.

3. Evaluasi alternatif, yaitu mengevaluasi pilihan terhadap produk dan merek dan memilihnya sesuai dengan keinginan konsumen dengan membandingkan berbagai pilihan yang dapat memecahkan masalah yang dihadapi.

4. Keputusan pembelian, setelah melakukan evaluasi terhadap berbagai alternatif, konsumen akan mengurangi jumlah alternatif yang akan dipertimbangkan selanjutnya akan memilih salah satu dan melakukan pembelian. Perilaku sesudah pembelian, kepuasan dan ketidakpuasan terhadap akan mempengaruhi pembelian selanjutnya bagi konsumen. 
Minat pembelian ulang menunjukkan keinginan pembeli untuk melakukan kunjungan ulang di masa yang akan datang. Perilaku pembelian ulang seringkali dikaitkan dengan loyalitas. Namun keduanya berbeda. Perilaku pembelian ulang hanya menyangkut pembelian ulang merek tertentu yang sama secara berulang ulang, sedangkan loyalitas merek mencerminkan komitmen psikologis terhadap merek tertentu.

Menurut Schiffman-Kanuk dalam Suwandi (2007: 3), "pembelian yang dilakukan oleh konsumen terdiri dari 2 tipe, yaitu pembelian percobaan dan pembelian ulang". Pembelian percobaan terjadi jika konsumen membeli suatu produk dengan merek tertentu untuk pertama kalinya, dimana dalam kegiatan tersebut konsumen berusaha menyelidiki dan mengevaluasi produk dengan langsung mencoba.

Keputusan pembelian ulang merupakan minat pembelian ulang yang menunjukkan keinginan konsumen untuk melakukan pembelian ulang (dalam Wahyu Ika Purnamasari, (2015) meliputi; kemudahan dalam mendapatkan produk, kegunaan yang dirasakan, kepercayaan, kenyamanan, pemenuhan, ketersesiaan layanan, ketanggapan.

\subsubsection{Promosi}

\section{Pengertian Promosi}

Pengertian Promosi Menurut Swastha (2000: 222), "promosi di pandang sebagai arus informasi atau persuasi satu arah yang di buat untuk mempengaruhi seseorang atau organisasi kepada tindakan yang menciptakan pertukaran dalam 
pemasaran". Promosi merupakan usaha perusahaan untuk membujuk konsumen, menarik minat konsumen baru,dan memperkenalkan produk kepada pasar.

Menurut Kusmono (2001: 374), definisi "promosi adalah usaha yang dilakukan pasar untuk mempengaruhi pihak lain agar berpartisipasi dalam kegiatan pertukaran". Promosi dapat berupa pemberian potongan harga, pemasangan iklan melalui media cetak maupun elektronik dan voucher. Bagi perusahaan yang baru berdiri kegiatan promosi menjadi sangat penting sebagai media untuk mengenalkan produk kepada pasar dan mendapatkan pasar, Menurut Suryana (2001: 112), “promosi adalah cara mengkomunikasikan barang dan jasa yang di tawarkan supaya konsumen mengenal dan membeli”.

Menurut Tjiptono (2001: 219) "Promosi adalah bentuk komunikasi pemasaran artinya aktivitas pemasaran yang berusahan menyebarkan informasi, mempengaruhi/membujuk dan atau mengingatkan pasar sasaran atas perusahaan dan produknya agar bersedia menerima, membeli dan loyal pada produk yang ditawarkan perusahaan yang bersangkutan”.

Berkaitan dengan uraian di atas, dapat disimpulkan bahwa promosi adalah upaya penginformasian atau penawaran produk umtuk menarik minat konsumen, promosi bisa berupa potongan harga, Iklan, dll.

\section{Bentuk - bentuk Promosi}

Melakukan kegiatan promosi terhadap beberapa variabel yang terkandung didalamnya, dan variabel-variabel tersebut harus dikombinasikan sesuai dengan kebutuhan dan kemampuan perusahaan. Kombinasi variabel-variabel promosi tersebut disebut dengan bauran promosi (promotional mix). Menurut Boone dan 
Kurtz (2001: 131), “Promotional mix terdiri dari dua komponen yaitu aktivitasaktivitas penjualan pribadi dan penjualan non-pribadi yang di kombinasikan oleh pemasar untuk memenuhi kebutuhan-kebutuhan pelanggan yang menjadi target perusahaan dan untuk mengkombinasikan pesannya secara efekif dan efesien kepada mereka".

Promosi dapat dilakukan dengan penjualan pribadi (personal selling) dan penjualan non pribadi (non personal selling) :

a. Penjualan pribadi (personal selling)

Menurut Madura (2001: 166), "Penjualan pribadi adalah presentasi penjulan secara personal yang di gunakan untuk mempengaruhi satu konsumen atau lebih". Penjualan ini memerlukan uapaya personal untuk mempengaruhi permintaan konsumen akan suatu produk.

b. Penjualan non pribadi (non personal selling)

Promosi penjualan non pribadi atau tidak secara langsung dapat dilakukan dengan beberapa cara salah satunya promosi penjualan. Menurut Madura (2001: 169) "Promosi penjualan adalah seragkaian aktivitas yang di maksudkan untuk mempengaruhi konsumen". Promosi penjualan ini menjadi efektif untuk mendoromg konsumen untuk membeli produk tertentu. Strastegi yang paling umum sebagai berikut:

a) Rabat

Rabat adalah potensi untuk mendapatkan pembayaran kembali dari produsen kepada konsumen. Jika produsen berkeinginan mengingatkan 
permintaan produk, selain menurunkan harga yang ditetapkan pada toko pengecer, mereka dapat juga memberikan rabat.

b) Kupon

Kupon adalah alat promosi yang digunakan dalam surat kabar, majalah, dan iklan untuk mendorong pembelian sebuah produk. Biasanya kupon juga dipaketkan dengan sebuah produk yang sama lagi. Kupon digunakan untuk mendorong konsumen untuk mengulangi pembelian produk yang sama. Akibatnya konsumen setia kepada mereka tersebut.

c) Sampling

Sampling adalah tindakan memberikan sample gratis yang mendorong konsumen untuk mencoba sebuah merek atau produk baru. Sample gratis yang mendorong konsumen untuk mencoba sebuah merek atau produk baru. Mereka mencoba membujuk pelanggan untuk menjauhi produk pesaing. Sample umumnya digunakan untuk memperkenalkan produk baru.

d) Display

Display digunakan untuk menarik konsumen yang berada di toko dengan alasan-alasan lain. Produk akan mendapatkan perhatian jika mereka diletakkan di lokasi inti perbelanjaan, seperti di sebelah mesin hitung dimana konsumen menunggu giliran pembayaran. 


\section{Indikator - indikator Promosi}

Indikator promosi dapat digunakan perusahaan sebagai tolak ukur apakah pesan yang ingin disampaikan oleh perusahaan sampai pada konsumen yang dituju. Menurut Kotler (2001) ada lima jenis kegiatan promosi antara lain :

1. Periklanan (Advertising)

Periklanan adalah bentuk promosi non personal dengan menggunakan berbagai media yang ditujukan untuk meningkatkan pembelian. Perusahaan menggunakan iklan sebagai media pengenalan produk kepada konsumen dan memungkinkan pelanggan mendapatkan informasi yang memadai mengenai produk yang dijual dipasar. Untuk mempertahankan produk agar tidak dilupakan oleh konsumen maka produsen harus melakukan periklanan berkala dan menghadirkan inovasi baru dalam memasarkan produk.

2. Promosi Penjualan

Promosi penjualan adalah berbagai insentif jangka pendek untuk mendorong keinginan mencoba atau membeli suatu produk/jasa. Tujuan promosi penjualan sangat beragam, perusahaan dapat menggunakan promosi penjualan untuk mendorong pembelian jangka panjang atau meningkatkan hubungan penjualan jangka pendek.

3. Personal selling

Personal selling atau penjualan tatap muka yaitu bentuk promosi secara personal dengan presentasi lisan dalam suatu percakapan dengan calon pembeli yang ditunjukkan untuk meningkatkan pembelian. Personal 
selling dianggap efektif dalam memasarkan produk karena seller dapat menjelaskan secara langsung kepada konsumen mengenai produknya,serta dapat membantu konsumen menemukan jenis produk yang sesuai dengan kebutuhannya.

\section{Publisitas}

Publisitas adalah bentuk promosi non personal mengenai pelayanan atau kesatuan usaha tertentu dengan jalan mengulas informasi atau berita tentangnya (pada umumnya bersifat ilmiah). Tujuan dari publisitas adalah untuk merangsang permintaan dari suatu produk secara non personal yang bersifat komersial mengenai produk tersebut di media elektronik maupun media cetak.

5. Pemasaran langsung dan iteraktif ( Direct Marketing)

Direct marketing adalah sistem pemasaran dimana perusahaan berkomunikasi secara langsung dengan target customer untuk mendapatkan respon. Komunikasi dalam direct marketing dapat dilakukan dengan penggunaan surel, telepon, dan alat penghubung non personal lainnya untuk mendapatkan tanggapan langsung dari calon pelanggan.

\subsubsection{Atribut Toko (Store Attributes )}

\section{a) Pengertian Atribut Toko (Store Attributes )}

Atribut toko dapat menimbulkan suatu perasaan pada konsumen sehingga konsumen tertarik untuk berbelanja. Pada umumnya toko yang baru menawarkan konsep yang berbeda baik dari tata letak barang, toko, maupun sistem pelayanan. 
"Sesuatu yang baru ini sangat menarik perhatian konsumen karena konsumen akan selalu mencari sesuatu yang baru, serta sangat menarik perhatian konsumen karena konsumen akan selalu mencari sesuatu yang baru sebagai penyegaran" (Jim \& Kim, 2001).

Samli (dalam Jim \& Kim, 2001) menjelaskan bahwa "Store image is the most important factor to retails and consumer, as consumers own self image”. Dapat didefiniskan bawha kesan toko adalah faktor yang sangat penting bagi pengecer dan konsumen, sebagaimana pilihan konsumen pada kesan toko yang sesuai dengan kesan konsumen sendiri. Wyckham (dalam Jim \& Kim, 2001) mengemukanan bahwa "kesan toko didefiniskan sebagai banyaknya semua atribut - atribut sebuah toko yang diamati oleh konsumen melalui pengalmanpengalaman mereka terhadap toko tersebut”.

Berkaitan dengan uraian di atas dapat disimpulkan bahwa atribut toko adalah salah satu daya tarik toko untuk membuat konsumen berkunjung, dan untuk menimbulkan sebuah kesan yang baik terhadap toko serta berkeinginan berbelanja kembali.

\section{b) Ruang Lingkup Atribut Toko (Store Attributes )}

Di dalam jurnal "Cultural influence on loyality tendency and evaluation of retail store attributes.” (Seock \& Lin, 2011: 96) mengutip teori Lindquist (1974) bersintesis mengenai konsep store attribute menjadi 9 dimensi yaitu sebagai berikut:

1. Merchandising, mengenai barang-barang yang dijualnya

2. Service, mengenai pelayanan yang diberikan 
3. Cliente, sifat pengunjung

4. Physical facilities, fasilitas fisik yang tersedia

5. Convenience, kenyamanan berbelajan

6. Promotion, promosi yang terlah dilakukan

7. Store atmosphere, mengenai atmosfir lingkukang toko

8. Instituational factors, mengenai fakto-faktor institusi (kelembagaan)

9. Past transacations, mengenai transaksi yang terdahulu

Dikarenakan keputusan konsumen sering diambil setelah berada di toko, karena informasi yang didapatkan konsumen diperoleh saat berbelanja di toko. "Maka dari itu berbagai perusahaan sering membuat atribut toko (Store Attribute) yang menarik" (Sumarwan,2002: 276).

\section{c) Indikator Atribut Toko (Store Attributes )}

Determinan keputusan pemilihan toko berbeda-beda menurut segmen pasar dan kelas produk.Menurut Engel F. Et al. (2003 ; 127-128) "karakteristik toko di tentukan dari atribut yang ditawarkan suatu toko yang mencangkup beberapa kategori yaitu lokasi, harga, kualitas barang, keragaman barang, pelayanan, promosi, fasilitas fisik, suasana, dan pelayanan purna jual”.

\section{Lokasi}

Atribut ini penting karena menyangkut beberapa komponen, yaitu deskripsi tempat, rasio parkir, arus pejalan kaki dan lalu lintas, akses transportasi umum, kondisi lingkungan dan vasibilitas. 
2. Harga

Persaingan antar toko dapat diakibatkan oleh perbedaan harga.Akan tetapi pentingnya harga tergantung dari sifat pembeli, karena sebagian konsumen yang lebih mementingkan faktor-faktor lain seperti kesenangan, kemudahan atau prestise. Harga dijelaskan dengan perbandingan ditempat lain atau harga pada umumnya dan dibagi menjadi empat pilihan, harga lebih tinggi dari harga di tempat lain, harga wajar atau kompetitif, harga bervariasi dari rendah sampai tinggi dan harga lebih murah.

3. Kualitas Barang

Atribut kualitas barang dijelaskan dengan selalu tersedianya barang berkualitas tinggi.Kualitas dapat dipercaya, umumnya barang dengan merek terkenal serta inovatif (mengikuti trend kebutuhan masyarakat).

4. Keragaman Barang

Atribut ini dapat didasarkan pada klasifikasi dasar produk, pemakaian akhir atau gaya hidup. Keragaman barang berdasarkan gaya hidup akan mengarah kepada bentuk toko barang spesial yang umumnya bergerak dalam niche atau celah pasar terbatas, sedangkan apabila berdasarkan klasifikasi dasar akan mengarah pada bentuk toko serba ada. Keragaman barang dijelaskan dengan ketersediaan macam-macam barang, ketersediaan pilihan merk untuk satu jenis barang dan ketersediaan barang yang tidak ada di toko lainnya. 
5. Pelayanan

ketersediaan pilihan merk untuk satu jenis barang dan ketersediaan barang yang tidak ada di toko lainnya.

6. Promosi

Atribut ini merupakan variabel yang cukup penting sehubungan dengan pemilihan toko.Promosi dapat dilakukan di dalam toko sekaligus di luar toko. Promosi penjualan dijelaskan dengan adanya diskon dalam periode tertentu (misalnya kejutan segar), dan diskon spesial (dalam event tertentu seperti lebaran, Natal, Tahun baru dan lain-lain).

7. Fasilitas Fisik

Konsumen akan mempertimbangkan fasilitas fisik seperti ketersediaan dan kemudahan parkir, keberadaan $\mathrm{AC}$ dan toilet, keberadaan toko lain dan daerah toko yang menentukan pilihan toko dan memberikan citra terhadap suatu toko.

8. Atmosfer

Untuk dapat membuat konsumen kerasan dan nyaman selama berbelanja, perlu diciptakan suasana toko yang menciptakan efek tertentu pada konsumen. Suasana toko dapat dijelaskan dengan desain muka toko atau pintu masuk dan etalase, pemilihan warna, pencahayaan dan musik, kebersihan, tata letak barang, penempatan harga atau merk, lalu lintas dalam toko atau kemudahan pemilihan barang serta keberadaan konsumen lain di dalam toko. 
9. Pelayanan Purna Jurnal

Pelanggan menginginkan kepuasan dan pelayanan sesudah pembelian, khususnya berlaku untuk pembelian barang dengan keterlibatan tinggi seperti perabot rumah tangga dan mobil.Atribut purna jual dijelaskan dengan pelayanan pengembalian barang, penukaran barang, garansi dan tanggapan keluhan telepon.

\subsubsection{Inovasi produk}

\section{Pengertian Inovasi Produk}

Definisi mengenai pengertian inovasi produk menurut Myers \& Marquis dalam Kotler (2007: 36) menyatakan bahwa "inovasi produk adalah gabungan dari berbagai macam proses yang saling mempengaruhi antara yang satu dengan yang lain". Jadi inovasi bukanlah konsep dari suatu ide baru, penemuan baru atau juga bukan merupakan suatu perkembangan dari suatu pasar yang baru saja, tetapi inovasi merupakan gambaran dari semua proses - proses tersebut.

Charles, et al (2002: 30) menyatakan bahwa "inovasi merupakan bagian dari kerangka kerja yang menghubungkan aspek budaya perusahaan dengan kemampuan berinovasi serta meningkatkan kinerja perusahaan melalui keputusan membeli konsumen". Dari pemikiran di atas dengan adanya inovasi produk yang dilakukan perusahaan, diharapkan dapat meningkatkan keputusan membeli ulang. Hal tersebut juga didukung oleh Kotabe dalam Tamamudin (2012: 289) yang menunjukkan bahwa "semakin tinggi inovasi produk yang dilakukan perusahaan maka akan meningkatkan kinerja perusahaan melalui peningkatan keputusan membeli". 
Dalam persaingan global, perusahaan harus dapat memodifikasi produknya untuk menambah nilai dari produk yang dihasilkannya dan harus dapat memenuhi kebutuhan dan selera konsumen. Nilai tambah dari produk yang dihasilkan dapat berupa desain / model dari produk yang dihasilkan dan pelayanan dari produk yang dijual. As Kilbourne \& Woodman dalam Sousa, et.al. (2012: 32) menunjukkan bahwa "sistem inovasi tergantung pada sejumlah variabel selain kreativitas, seperti otonomi, informasi yang tersedia, sistem imbalan, pendidikan atau pelatihan, sistem authority, partisipasi dalam pengambilan keputusan, atau kekompakan tim".

Sedangkan Hurley \& Hult (1998: 45) mendefinisikan “inovasi sebagai sebuah mekanisme perusahaan untuk beradaptasi dalam lingkungan yang dinamis, oleh karena itu perusahaan dituntut untuk mampu menciptakan pemikiran pemikiran baru, gagasan - gagasan baru, dan menawarkan produk yang inovatif serta peningkatan pelayanan yang memuaskan pelanggan”.

Berkaitan dengan uraian di atas, dapat disimpulkan bahwa inovasi produk adalah gambaran dari berbagai proses mulai dari konsep suatu ide baru, penemuan baru dan suatu perkembangan dari suatu pasar yang baru yang saling mempengaruhi antara yang satu dengan yang lain.

\section{Indikator Inovasi Produk}

Gatignon \& Xuereb (1997: 71) “mengemukakan 3 (tiga) karakteristik inovasi yaitu keunggulan produk, biaya produk dan kredibilitas produk”. Produk inovasi dapat gagal hanya alasan tidak menawarkan desain yang unik atau salah perkiraan akan keinginan dan kebutuhan pelanggan. Inovasi produk seharusnya 
mampu memberikan nilai tambah disbanding produk sejenis (keunggulan produk) sehingga dapat menjadikan perusahaan memiliki keunggulan dibandingkan dengan pesaingnya. Lukas \& Ferrell (2000: 240) menjelaskan adanya beberapa indikator dari invosi produk, yaitu:

a) Perluasan lini (line extensions) yaitu produk yang dihasilkan perusahaan tidaklah benar-benar baru tetapi relative baru untuk sebuah pasar.

b) Produk baru (me too - product) yaitu produk baru bagi perusahaan tetapi tidak baru bagi pasar.

c) Produk benar-benar baru (new - to - the - world - product) adalah produk yang termasuk baru baik bagi perusahaan maupun pasar.

Terdapat enam golongan inovasi produk antara lain (Kotler, 2007: 37) sebagai berikut:

a) Produk baru bagi dunia

Produk baru bagi dunia merupakan suatu produk baru yang menciptakan pasar yang sama sekali baru, dimana produk sejenis belum pernah dibuat oleh pihak lain sehingga produk tersebut merupakan produk yang benarbenar baru sehingga dapat membedakan produk baru tersebut dengan produk - produk sejenis yang lainnya.

b) Lini produk baru

Lini produk baru merupakan produk baru yang memungkinkan perusahaan memasuki pasar yang telah mapan untuk pertama kalinya memasuki pasar yang sudah ada, dengan lini produk baru dapat mempengaruhi konsumen untuk menentukan pilihan produk. 
c) Tambahan pada lini produk yang telah ada

Tambahan pada lini produk yang telah ada merupakan produk - produk baru yang melengkapi atau menambah suatu lini produk perusahaan yang telah mantap sehingga produk menjadi lebih beragam sehingga memunculkan banyak pilihan.

d) Perbaikan dan revisi produk yang telah ada

Perbaikan dan revisi produk yang telah ada merupakan produk yang memberikan kinerja yang lebih baik atau nilai yang dianggap lebih hebat dan menggantikan produk yang telah ada, dimana dihasilkan produk baru dengan daya kerja/kegunaan yang disempurnakan.

e) Penentuan kembali

Penentuan kembali merupakan produk yang sudah ada diarahkan atau dipasarkan ke pasar atau segmen pasar yang baru, hasil ini diharapkan dapat memperluas pemasaran dengan memperoleh pangsa pasar atau konsumen baru sebagai upaya untuk meningkatkan penjualan.

f) Pengurangan biaya

Pengurangan biaya merupakan produk baru yang menyediakan produk yang daya kerja/kegunaanya serupa dengan harga yang lebih murah atau rendah, hal ini dimaksudkan mempengaruhi keputusan konsumen untuk membeli suatu produk dan hal ini berdampak pada meningkatnya volume penjualan suatu produk.

Adanya kesamaan tampilan produk sejenis dari pesaing merupakan faktor pendorong terjadinya inovasi produk, umumnya produk pesaing itu muncul tanpa 
mengalami perubahan yang berarti bahkan cenderung statis. Keadaan seperti ini dapat menjadi hal yang menguntungkan, karena persaingan yang timbul dengan munculnya produk pesaing dapat diatasi dengan melakukan inovasi produk. Inovasi produk merupakan sesuatu yang dapat dilihat sebagai kemajuan fungsional produk yang dapat membawa produk selangkah lebih maju dibandingkan dengan produk pesaing. Apabila produk tersebut memiliki suatu kelebihan yang dipandang sebagai nilai tambah bagi konsumen. Pengembangan produk baru memerlukan upaya, waktu dan kemampuan termasuk besarnya risiko dan biaya kegagalan.

\section{Inovasi Proses}

Inovasi proses adalah suatu elemen baru yang diperkenalkan dalam operasi produk dan jasa dalam perusahaan, seperti materi bahan baku, spesifikasi tugas, mekanisme kerja dan informasi, maupun peralatan yang digunakan untuk memproduksi produk atau jasa.

\section{Inovasi Administrasi}

Inovasi ini sangat berkaitan dengan perubahan dalam metode operasi bisnis yang dapat memanfaatkan perubahan tersebut secara efektif dalam struktur dan kebijaksanaan organisasi, metode kerja, dan prosedur lainnya untuk memproduksi, membiayai, dan memasarkan produk atau jasa. Inovasi administrasi turut melibatkan perubahan yang berpengaruh terhadap kebijakankebijakan organisasi, alokasi sumber daya, dan faktor-faktor lain yang berkaitan dengan struktur sosial organisasi yang secara tidak langsung berkaitan dengan kegiatan dasar organisasi. 
Menurut Hubeis dalam Sya'roni \& Sudirham (2012: 4) dikemukakan empat indikator inovasi, yaitu :
a. Penemuan
b. Pengembangan
c. Duplikasi dan
d. Sintetis

Berdasarkan uraian tersebut maka indikator inovasi digunakan pada penelitian ini meliputi : produk baru bagi dunia, lini produk baru, tambahan pada lini produk yang telah ada, perbaikan dan revisi produk yang telah ada, penentuan kembali dan pengurangan biaya.

\subsection{Penelitian terdahulu}

Berikut ini beberapa literature dan penelitian terdahulu tentang promosi, atribut toko (Store Attributes), dan inovasi produk terhadap kepuasan pembelian ulang :

Tabel 2.1

\section{Penelitian Terdahulu}

\begin{tabular}{|c|l|l|l|}
\hline No & \multicolumn{1}{|c|}{ Peneliti } & \multicolumn{1}{|c|}{ Judul Penelitian } & \multicolumn{1}{c|}{ Hasil Penelitian } \\
\hline 1. & $\begin{array}{l}\text { Dwi Yuli Astuti } \\
\mathbf{( 2 0 1 8 )}\end{array}$ & $\begin{array}{l}\text { Pengaruh harga } \\
\text { promosi terhadap } \\
\text { minat pembelian } \\
\text { ulang Pada evaluasi } \\
\text { pembeli starbucks } \\
\text { coffee di yogyakarta }\end{array}$ & $\begin{array}{l}\text { Hasil dari penelitian ini bahwa } \\
\text { pembeli puas dengan makanan } \\
\text { dan minuman yang disajikan } \\
\text { Starbucks Coffee merupakan } \\
\text { faktor yang paling penting dalam } \\
\text { menilai variabel } \\
\text { Kepuasan. }\end{array}$ \\
\hline 2. & $\begin{array}{l}\text { Intan } \\
\text { Mawarsari } \\
\mathbf{( 2 0 1 8 )}\end{array}$ & $\begin{array}{l}\text { Pengaruh kualitas } \\
\text { produk, harga, dan } \\
\text { promosi terhadap } \\
\text { minat beli ulang } \\
\text { konsumen olahan } \\
\text { buah carica di daerah }\end{array}$ & $\begin{array}{l}\text { Hasil dari penelitian ini bahwa } \\
\text { harga, dan promosi berpengaruh } \\
\text { terhadap minat beli ulang, } \\
\text { sedangkan kualitas produk tidak } \\
\text { berpengaruh }\end{array}$ \\
\hline
\end{tabular}




\begin{tabular}{|c|c|c|c|}
\hline & & Wonosobo & \\
\hline 3. & $\begin{array}{l}\text { Younes Ben } \\
\text { Said, Nicola } \\
\text { Luigi Bragazzi, } \\
\text { and Natalia } \\
\text { Valeryevna } \\
\text { Pyatigorskaya } \\
\text { (2019) }\end{array}$ & $\begin{array}{l}\text { Influence of Sales } \\
\text { Promotion } \\
\text { Techniques on } \\
\text { Consumers, } \\
\text { Purchasing } \\
\text { Decisions at } \\
\text { Community } \\
\text { Pharmacies }\end{array}$ & $\begin{array}{l}\text { The research findings identified } \\
\text { that, according to all respondents, } \\
\text { the following sales promotion } \\
\text { tools had the strongest impact on } \\
\text { consumers' purchasing decisions: } \\
\text { arrangement and design of } \\
\text { showcases among the studied } \\
\text { tools for merchandising; buy } 1 \\
\text { and get 2, and discounts among } \\
\text { the studied tools for consumer } \\
\text { promotion; and gifts among the } \\
\text { trade promotion studied tools. The } \\
\text { findings showed that the same } \\
\text { tools were named as the most } \\
\text { common by all respondents. The } \\
\text { tool free sample of promoted } \\
\text { products appeared to be the most } \\
\text { prevalent, but, at the same time, } \\
\text { was the least e_ective. }\end{array}$ \\
\hline 4. & $\begin{array}{l}\text { Silvia Warliana } \\
\text { (2013) }\end{array}$ & $\begin{array}{l}\text { Pengaruh atribut } \\
\text { toko terhadap } \\
\text { keputusan Pembelian } \\
\text { konsumen pada } 999 \\
\text { mini swalayan } \\
\text { soekarno hatta Pekan } \\
\text { baru }\end{array}$ & $\begin{array}{l}\text { Hasil dari penelitian ini adalah } \\
\text { Kebijakan yang diterapkan oleh } \\
999 \text { mini swalayan terhadap } \\
\text { atribut toko yang dapat } \\
\text { mempengaruhi keputusan } \\
\text { pembelian konsumen dengan } \\
\text { tujuan meningkatkan penjualan } \\
\text { sudah bagus. Hal tersebut dapat } \\
\text { dilihat dari semakin meningkatnya } \\
\text { hasil penjualan } 999 \text { mini } \\
\text { swalayan karena kebijakan yang } \\
\text { di terapkapkan sesuai dengan } \\
\text { harapan dan keinganan dan } \\
\text { kebutuhan konsumen. }\end{array}$ \\
\hline 5. & $\begin{array}{l}\text { Muhyidin } \\
\text { (2017) }\end{array}$ & $\begin{array}{l}\text { Pengaruh atribut } \\
\text { toko terhadap } \\
\text { keputusan pembelian } \\
\text { barang di toko ritel } \\
\text { (studi khasus pada } \\
\text { toko basmalah pada } \\
\text { cabang rembang } \\
\text { kabupaten pasuruan } \\
\text { jawa timur) }\end{array}$ & $\begin{array}{l}\text { Hasil dri penelitian ini } \\
\text { bahwasannya atribut toko sangat } \\
\text { berpengaruh terhadap keputusan } \\
\text { pembelian, dari } 7 \text { variabelnya } \\
\text { harga adalah variabel yang pling } \\
\text { berpengaruh besar terhadap } \\
\text { keputusan pembelian }\end{array}$ \\
\hline 6. & $\begin{array}{l}\text { Ms. } \\
\text { D.Alamemu }\end{array}$ & $\begin{array}{l}\text { A Study on the } \\
\text { Attributes }\end{array}$ & $\begin{array}{l}\text { However all the five attributes } \\
\text { quality, price, appeal, brand and }\end{array}$ \\
\hline
\end{tabular}




\begin{tabular}{|c|c|c|c|}
\hline & (2018) & $\begin{array}{l}\text { Influencing the } \\
\text { Purchasing } \\
\text { Behaviour of } \\
\text { Apparel Consumer } \\
\text { in Organized Retail } \\
\text { with Special } \\
\text { Reference to Max } \\
\text { Retail Division }\end{array}$ & $\begin{array}{l}\text { variety influence each other in } \\
\text { which variety and brandhas a } \\
\text { moderate positive correlation } \\
\text { while purchasing a product from } \\
\text { the outlet. } \\
\text { Finally to conclude the retail } \\
\text { managers should emphasis and } \\
\text { strengthen availability of more } \\
\text { collections with latest design ease } \\
\text { of pick and choice and value for } \\
\text { their money for which consumers } \\
\text { give more priority. Since the outlet } \\
\text { has got its own brand image and } \\
\text { value in the industry, as well as in } \\
\text { the geographical area, the store } \\
\text { should maintain their relationship } \\
\text { with the customer and will } \\
\text { transmute them as loyal } \\
\text { customers inthe near future. }\end{array}$ \\
\hline 7. & $\begin{array}{l}\text { Intan firdausi } \\
\text { (2016) }\end{array}$ & $\begin{array}{l}\text { Pengaruh Inovasi } \\
\text { Produk, Daya Tarik } \\
\text { Ildan dan Persepsi } \\
\text { Harga terhadap } \\
\text { Keputusan } \\
\text { Pembelian pada Cafe } \\
\text { dengan Menu Unik } \\
\text { (Studi kasus pada } \\
\text { Cafe Tombo Ngelak } \\
\text { Yogyakarta) }\end{array}$ & $\begin{array}{l}\text { Hasil dari penelitian ini Inovasi } \\
\text { produk, daya tarik iklan dan } \\
\text { persepsi harga berpengaruh secara } \\
\text { simultan terhadap keputusan } \\
\text { pembelian. Hal ini di buktikan } \\
\text { dengan hasil pengujian diperoleh } \\
\text { nilai F hitung sebesar } 53,433 \\
\text { dengan signifikansi } \\
\text { sebesar } 0,000<0,05 \text {. }\end{array}$ \\
\hline 8. & $\begin{array}{l}\text { Bangun dwi } \\
\text { prasetio (2016) }\end{array}$ & $\begin{array}{l}\text { Pengaruh inovasi } \\
\text { produk dan kualitas } \\
\text { pelayanan terhadap } \\
\text { keputusan pembelian } \\
\text { pada batik zhorif di } \\
\text { kecamatan danau } \\
\text { teluk jambi kota } \\
\text { seberang }\end{array}$ & $\begin{array}{l}\text { Hasil dari penelitian ini adalah } \\
\text { terdapat pengaruh inovasi produk } \\
\text { terhadap keputusan pembelian } \\
\text { yang ditinjau dengan nilai regresu } \\
\text { sebesar 0.628. nilai tersebut } \\
\text { menunjukan pengaruh yang kuat. } \\
\text { R square (koefisien determinasi/ } \\
\text { R2) sebesar 0,394 menunjukkan } \\
\text { bahwa 39,40\% keputusan } \\
\text { pembelian ditentukan oleh inovasi } \\
\text { produk yang diberikan batik } \\
\text { zhorif. }\end{array}$ \\
\hline 9. & $\begin{array}{l}\text { Tamamudin } \\
(2012)\end{array}$ & $\begin{array}{l}\text { Analisis pengaruh } \\
\text { Pengenalan merek, } \\
\text { persepsi Kualitas, } \\
\text { harapan konsumen } \\
\text { Dan inovasi produk }\end{array}$ & $\begin{array}{l}\text { Hasil dari penelitian ini adalah } \\
\text { dapat disimpulkan dimensi- } \\
\text { dimensi inovasi produk akan } \\
\text { berpengaruh terhadap keputusan } \\
\text { membeli. Hasil penelitian ini } \\
\end{array}$ \\
\hline
\end{tabular}




\begin{tabular}{|l|l|l|l|}
\hline & $\begin{array}{l}\text { terhadap Keputusan } \\
\text { membeli dan } \\
\text { dampaknya } \\
\text { Pada loyalitas } \\
\text { konsumen } \\
\text { (studi kasus: produk } \\
\text { batik sutra halus } \\
\text { merek tamina) }\end{array}$ & $\begin{array}{l}\text { konsisten dengan penelitian Noble } \\
\text { et al., (2002) yang menunjukkan } \\
\text { bahwa inovasi } \\
\text { produk mampu meningkatkan } \\
\text { keputusan membeli. }\end{array}$ \\
\hline 10. & $\begin{array}{l}\text { Pengaruh Promosi, } \\
\text { Marasian } \\
\text { (2017) }\end{array}$ & $\begin{array}{l}\text { Harga, Kualitas } \\
\text { Pelayanan Terhadap } \\
\text { Kepuasan Konsumen } \\
\text { dan Keputusan } \\
\text { pembelian Ulang di } \\
\text { alfamart dan } \\
\text { indomaret (studi di } \\
\text { alfamart dan } \\
\text { indomaret waralaba } \\
\text { di jalan ratu dibalau } \\
\text { tanjung senang, } \\
\text { bandar lampung) }\end{array}$ & $\begin{array}{l}\text { Kualitas pelayanan, dan } \\
\text { keputusan pembelian ualng } \\
\text { berpengaruh signifikan terhadap } \\
\text { kepuasan konsumen. Hasil uji f } \\
\text { menunjukan bahwa terdapat } \\
\text { pengaruh Promosi, harga, kualitas } \\
\text { pelayanan terhadap kepuasan } \\
\text { konsumen dankeputusan } \\
\text { pembelian ulang berpengaruh } \\
\text { signifikan di alfamart dan } \\
\text { indomaret jalan ratu dibalau } \\
\text { tanjung senang, bandar lampung }\end{array}$ \\
\hline
\end{tabular}

\subsection{Pengaruh Antar Variabel}

Hubungan antar variabel ini menjelaskan keterkaitan variabel (hubungan) kualitas produk dan pelayanan terhadap kepuasan pelanggan.

\subsubsection{Pengaruh Variabel Promosi terhadap Keputusan Pembelian Ulang}

Promosi adalah salah satu cara yang di berikan oleh pasar untuk dapat menginformasikan dan memberi pengeruh kepada konsumen atau masyarakat yang dapat membuat tertarik pembeli atau konsumen. Promosi dapat berupa pemberian potongan harga, pemasangan iklan melalui media cetak maupun elektronik dan voucher. Promosi sebagai penunjang untuk meningkatkan pembelian. "Promosi merupakan suatu komunikasi informasi penjual dan pembeli yang bertujuan untuk merubah sikap dan tingkah laku pembeli, yang tadinya tidak 
mengenal menjadi mengenal sehingga menjadi pembeli dan tetap mengingat produk tersebut" (Saladin, 2002: 123). "Dengan adanya promosi maka pelanggan akan membeli kembali atau melakukan pembelian ulang. pertimbangan individu terkait dengan pembelian ulang suatu produk dari suatu perusahaan yang dipengaruhi oleh kondisi lingkungan sekitarnya" (Hellier et al., (2003), Spais \& Vasileiou, (2006), Atchariyachanvanich et al., (2006), dalam Sylvi (2009), dari definisi diatas dapat disimpulkan jika kondisi suatu lingkungan tersebut baik, maka potensi terjadinya pembelian ulang juga akan semakin tinggi. Jika kondisi lingkungan yang ada buruk, maka potensi terjadinya pembelian ulang pun juga rendah.

\subsubsection{Pengaruh Variabel Atribut Toko (Store Attributes) terhadap Keputusan Pembelian Ulang}

Menurut Rusidan (1999) dalam Wismoyo Ari P (2012: 21), menyatakan bahwa "strategi atmosfir toko (atribut toko) dalah suatu dengan melibatkan atribut toko untuk menarik keputusan pemebelian konsumen". Selain itu, Michael R Solomon(1992 : 316) dalam Jin dan Kim (2001: 146). Juga "menambahkan bahwa atmospherics atau suasana yang tercipta dalam tempat perbelanjaan juga menjadi penentu apakah tempat tersebut menjadi pilihan konsumen atau tidak". Dapat disimpulkan dari hasil penelitian diatas bahwa atribut toko merupakan salah satu daya tarik toko untuk membuat konsumen berkunjung. Dan untuk menimbulkan sebuah kesan yang baik terhadap toko serta berkeinginan berbelanja kembali ditoko. Dengan demikian maka kosumen akan kembali dan melakukan pembelian ulang di sana. 


\subsubsection{Pengaruh Variabel Inovasi Produk Terhadap Keputusan Pembelian Ulang}

Untuk melakukan pembelian, konsumen tidak terlepas dari karakteristik produk baik mengenai penampilan, gaya, mutu dan harga dari produk tersebut. Penempatan harga oleh penjual akan bepengaruh terhadap perilaku pembelian konsumen, sebab harga yang dapat dijangkau oleh konsumen akan cenderung membuat konsumen melakukan pembelian ulang terhadap produk tersebut.

Adapun penelitian sebelumnya yang mendukung adalah penelitian yang dilakukan oleh Lamb, et al. (2002: 30) menunjukan bahwa "inovasi merupakan bagian dari kerangka yang menghubungkan aspek budaya perusahaan dengan kemampuan berinovasi serta meningkatkan kinerja perusahaan melalui keputusan membeli konsumen”. Demikian juga penelitian Tamamudin (2012: 283) menunjukan bahwa terdapat pengaruh yang signifikan inovasi produk terhadap keputusan pembelian, semakin tinggi inovasi produk maka semakin tinggi keputusan pembelian.

Kotler dan Armstrong (2008:184), bahwa "produk baru (inovasi produk) adalah barang, jasa, atau ide yang dianggap baru oleh sejumlah pelanggan potensial". Produk baru mungkin telah ada untuk beberapa waktu, tetapi ketertarikan kita terletak pada bagaimana konsumen mempelajari produk itu untuk pertama kalinya dan membuat keputusan untuk membelinya. Terdapat beberapa persamaan dan perbedaan antara penelitian ini dengan penelitian yang dilakukan oleh Susanto (2017) dan Shaleh (2017). Persamaan penelitian ini dengan penelitian yang dilakukan oleh Susanto (2017) dan Shaleh (2017) adalah memiliki variabel terikat yang sama yaitu Keputusan Pembelian. 


\subsubsection{Pengaruh Variabel Promosi, Atribut Toko (Store Attribute), dan Inovasi Produk terhadap Keputusan Pembelian Ulang}

Pengertian promosi menurut Tjiptono (2001: 219) adalah "bentuk komunikasi pemasaran artinya aktivitas pemasaran yang berusahan menyebarkan informasi, mempengaruhi/membujuk dan atau mengingatkan pasar sasaran atas perusahaan dan produknya agar bersedia menerima, membeli dan loyal pada produk yang ditawarkan perusahaan yang bersangkutan". Atribut toko dapat menimbulkan suatu perasaan pada konsumen sehingga konsumen tertarik untuk berbelanja. Samli (dalam Jim \& Kim, 2001) menjelaskan bahwa "Store image is the most important factor to retails and consumer, as consumers own self image". Dapat didefiniskan bawha kesan toko adalah faktor yang sangat penting bagi pengecer dan konsumen, sebagaimana pilihan konsumen pada kesan toko yang sesuai dengan kesan konsumen sendiri.

Inovasi produk adalah gambaran dari berbagai proses mulai dari konsep suatu ide baru, penemuan baru dan suatu perkembangan dari suatu pasar yang baru yang saling mempengaruhi antara yang satu dengan yang lain. As Kilbourne \& Woodman dalam Sousa, et.al. (2012: 32) “menunjukkan bahwa sistem inovasi tergantung pada sejumlah variabel selain kreativitas, seperti otonomi, informasi yang tersedia, sistem imbalan, pendidikan atau pelatihan, sistem authority, partisipasi dalam pengambilan keputusan, atau kekompakan tim”.

Pada dasarnya keputusan pembelian ulang sendiri terjadi dikarenakan adanya faktor kepuasan konsumen, yang dimana seorang konsumen merasakan manfaat dan mendapatkan kepuasan dari pengonsumsian produk/jasa sehingga 
berniat untuk melakukan pengonsumsian kembali terhadap produk tersebut di lain waktu.

\subsection{Kerangka Teoritik}

Jadi promosi, Atribut Toko (Store Attributes) dan inovasi produk akan meningkatkan keputusan pembelian ulang pada Nick coffe, agar tujuan dari usaha tersebut tercapai. Untuk memperjelas variabel - variabel yang mempengaruhi keputusan pembelian ulang, maka penulis membuat kerangka konseptual sebagai berikut :

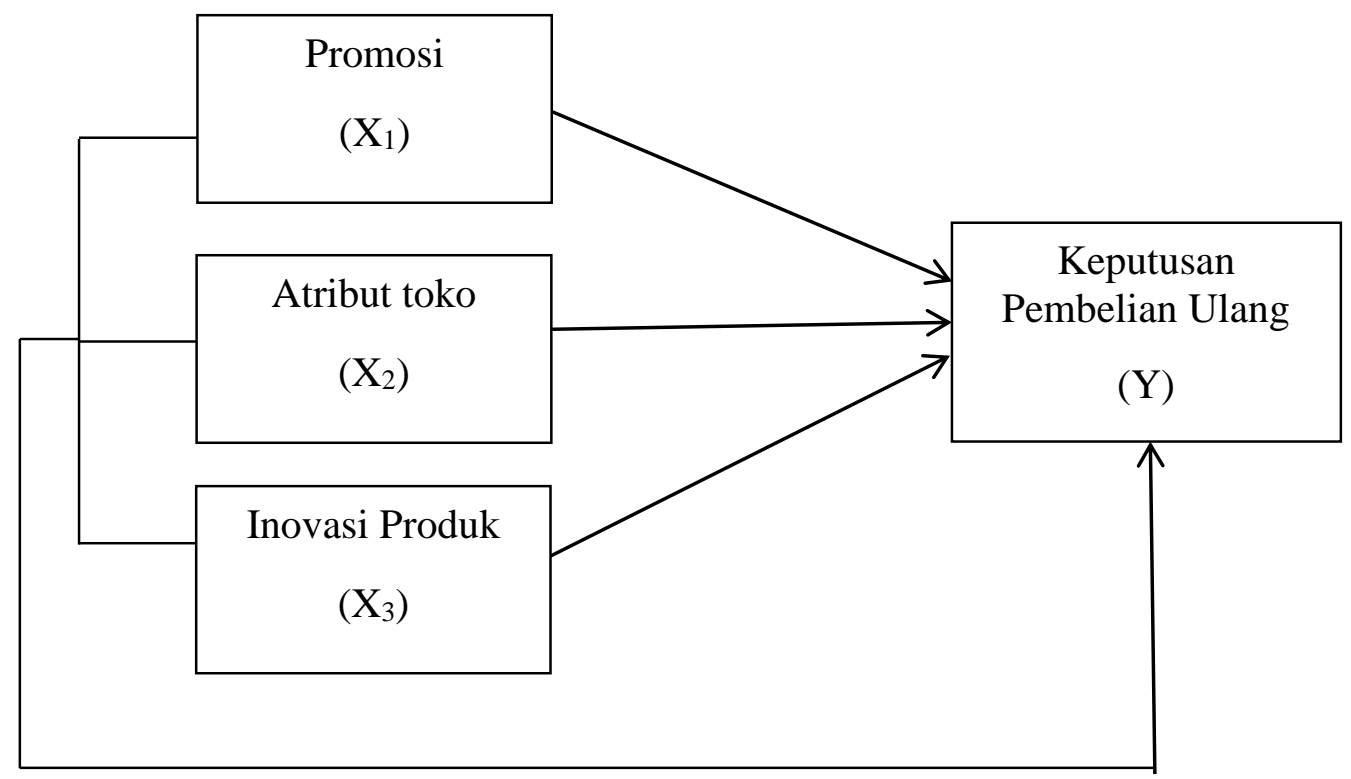

Gambar 2.1 Kerangka konseptual penelitian

Keterangan:

$\mathrm{X}=$ Variabel berpengaruh terhadap ( Independen )

$\mathrm{Y}=$ Variabel berpengaruhi terhadap ( Dependen )

$\rightarrow=$ Pengaruh 


\subsection{Definisi Operasional}

Definisi operasional adalah suatu definisi yang diberikan kepada suatu variabel dengan cara memberikan arti atau menspesifikasikan kegiatan, ataupun operasional yang diperlukan untuk mengukur variabel tersebut, adapun defenisi dari masing-masing variabel ini adalah sebagai berikut:

Tabel 2.2 Definisi Operasional Variabel

\begin{tabular}{|c|c|c|c|c|}
\hline No & Variabel & Difinisi & Indikator & Skala \\
\hline 1. & $\begin{array}{l}\text { Promosi } \\
\left(\mathbf{X}_{1}\right)\end{array}$ & $\begin{array}{l}\text { promosi adalah upaya } \\
\text { penginformasian atau } \\
\text { penawaran produk umtuk } \\
\text { menarik minat konsumen, } \\
\text { promosi bisa berupa } \\
\text { potongan harga, Iklan, dll. }\end{array}$ & $\begin{array}{l}\text { 1) Periklanan } \\
\text { (Advertising ) } \\
\text { 2) Promosi } \\
\text { Penjualan } \\
\text { 3) Personal selling } \\
\text { 4) Publisitas } \\
\text { 5) Pemasaran } \\
\text { langsung dan } \\
\text { iteraktif ( Direct } \\
\text { Marketing) } \\
\text { (Menurut Kotler, } \\
\text { 2001) }\end{array}$ & Ordinal \\
\hline 2. & $\begin{array}{l}\text { Atribut } \\
\text { Toko } \\
\text { (Store } \\
\text { Attributes) } \\
\left(\mathrm{X}_{2}\right)\end{array}$ & $\begin{array}{l}\text { atribut toko adalah salah } \\
\text { satu daya tarik toko untuk } \\
\text { membuat konsumen } \\
\text { berkunjung, dan untuk } \\
\text { menimbulkan sebuah kesan } \\
\text { yang baik terhadap toko } \\
\text { serta berkeinginan } \\
\text { berbelanja kembali . }\end{array}$ & $\begin{array}{l}\text { 1) Lokasi } \\
\text { 2) Harga } \\
\text { 3) Kualitas Barang } \\
\text { 4) Keragaman } \\
\text { Barang } \\
\text { 5) Pelayanan } \\
\text { 6) Promosi } \\
\text { 7) Fasilitas Fisik } \\
\text { 8) Atmosfer } \\
\text { 9) Pelayanan Purna } \\
\text { Jual } \\
\text { Engel F. Et al. } \\
\text { (2003 ; 127-128) }\end{array}$ & Ordinal \\
\hline
\end{tabular}




\begin{tabular}{|c|c|c|c|c|}
\hline 3. & $\begin{array}{l}\text { Inovasi } \\
\text { Produk } \\
\left(\mathbf{X}_{3}\right)\end{array}$ & $\begin{array}{l}\text { Inovasi Produk adalah } \\
\text { gambaran dari berbagai } \\
\text { proses mulai dari konsep } \\
\text { suatu ide baru, penemuan } \\
\text { baru dan suatu } \\
\text { perkembangan dari suatu } \\
\text { pasar yang baru yang saling } \\
\text { mempengaruhi antara yang } \\
\text { satu dengan yang lain. }\end{array}$ & $\begin{array}{l}\text { 1) Produk baru bagi } \\
\text { dunia } \\
\text { 2) Lini produk baru } \\
\text { 3) Tambahan pada } \\
\text { lini produk yang } \\
\text { telah ada } \\
\text { 4) Perbaikan dan } \\
\text { revisi produk } \\
\text { yang telah ada } \\
\text { 5) Penentuan } \\
\text { kembali } \\
\text { 6) Pengurangan } \\
\text { biaya } \\
\text { (Kotler,2007:37) }\end{array}$ & Ordinal \\
\hline 4. & $\begin{array}{l}\text { Keputusan } \\
\text { Pembelian } \\
\text { Ulang }(Y)\end{array}$ & $\begin{array}{l}\text { Keputusan Pembelian Ulang } \\
\text { adalah perasaan puas } \\
\text { seseorang dengan begitu } \\
\text { ketika seseorang merasa } \\
\text { puas akan terjadinya } \\
\text { pembelian berulang. }\end{array}$ & $\begin{array}{ll}\text { 1) } & \begin{array}{l}\text { Pengenalan } \\
\text { kebutuhan }\end{array} \\
\text { 2) } & \text { Pencarian } \\
\text { informasi } \\
\text { 3) Evaluasi } \\
\text { alternatif } \\
\text { 4) Keputusan } \\
\text { pembelian } \\
\text { 5) Perilaku setelah } \\
\text { pembelian } \\
\text { (Kotler dan } \\
\text { Amstrong : 2004) }\end{array}$ & Ordinal \\
\hline
\end{tabular}

\subsection{Hipotesis}

Hipotesis penelitian merupakan jawaban sementara terhadap pertanyaan yang diajukan dalam identifikasi masalah. Hipotesis tersebut harus diuji atau dibuktikan kebenarannya lewat pengumpulan dan penganalisisan data-data. Berdasarkan data-data diatas penulisan menyusun hipotesis sebagai berikut:

$\mathrm{H}_{1}=$ Diduga Promosi berpengaruh positif terhadap Keputusan Pembelian Ulang pada konsumen Nick Coffe. 
$\mathrm{H}_{2}=$ Diduga Atribut toko (Store Attributes) berpengaruh positif terhadap Keputusan Pembelian Ulang pada konsumen Nick Coffe.

$\mathrm{H}_{3}=$ Diduga Inovasi Produk berpengaruh positif terhadap Keputusan Pembelian Ulang pada konsumen Nick Coffe.

$\mathrm{H}_{4}=$ Diduga Promosi, Atribut Toko (Store Attributes), dan Inovasi Produk berpengaruh positif terhadap Keputusan Pembelian Ulang pada konsumen Nick Coffe. 


\section{BAB III}

\section{METODE PENELITIAN}

\subsection{Tempat Dan Waktu Penelitian}

Lokasi penelitian berada di Kota Bengkulu tepatnya yang beralamat di Rumah Makan Pringgading, Jalan Ciliwung Bawah, No 33 Kota Bengkulu, cafe ini dibuka mulai dari jam 10.00 - 23.00. Penelitian ini dilakukan mulai dari bulan 20 Januari sampai 20 Februari 2020, kurang lebih selama 1 bulan.

\subsection{Jenis penelitian}

Jenis penelitian ini merupakan jenis penelitian deskriptif kuantitatif, karena dalam penelitian ini mendeskripsikan keadaan yang terjadi pada saat sekarang secara sistematis dan faktual dengan tujuan untuk memaparkan serta penyelesaian dari masalah yang diteliti.

Menurut Arikunto (2010) "Penelitian Deskriptif adalah penelitian yang dimaksudkan untuk menyelidiki keadaan, kondisi atau hal-hal lain yang sudah disebutkan, yang hasilnya dipaparkan dalam bentuk laporan penelitian. Peneliti tidak mengubah, menambah, atau mengadakan manipulasi terhadap objek atau wilayah penelitian. Peneliti hanya memotret apa yang terjadi pada diri objek atau wilayah yang diteliti, kemudian memaparkan apa yang terjadi dalam bentuk laporan penelitian secara lugas, seperti apa adanya."

Menurut Nawawi (1991) metode deskriptif adalah prosedur pemecahan masalah yang diselidiki dengan menggambarkan/melukiskan keadaan, subjek atau objek penelitian (seseorang, lembaga, masyarakat dan lainlain) pada saat sekarang berdasarkan fakta-fakta yang tampak sebagaimana adanya jika dilihat dari segi metode penelitian maka penelitian ini menggunakan metode survey Sugiyono (2013) mengatakan bahwa metode survey adalah metode yang digunakan untuk mendapatkan data dari tempat tertentu yang alamiah (bukan buatan), tetapi peneliti melakukan perlakuan dalam pengumpulan data, misalnya dengan 
mengedarkan kuesioner, test, wawancara terstruktur, dan sebagainya. Penelitian ini termasuk dalam penelitian kuantitatif. Menurut Martono (2015) "penelitian kuantitatif merupakan penelitian yang menggunakan metode kuantitatif, yaitu sebuah metode penelitian yang bertujuan menggambarkan fenomena atau gejala sosial secara kuantitatif atau menjelaskan bagaimana fenomena atau gejala sosial yang terjadi di masyarakat saling berhubungan satu sama lain".

Metode deskriptif kuantitatif dalam penelitian ini adalah metode yang digunakan dalam menyelesaikan suatu penelitian ilmiah dengan tujuan untuk memecahkkan masalah yang sedang diteliti yaitu tentang pengaruh Promosi, Atribut toko (Store Attributes), dan Inovasi Produk terhadap Keputusan Pembelian Pada Nick coffe Bengkulu.

\subsection{Populasi dan Sampel}

Populasi dan sampel ini adalah sebagai bahan objek untuk memulai penelitian dan sebagai sumber untuk mendapatkan dan mencari data penelitian adapun populasi dan sampel yang telah ditentukan.

\subsubsection{Populasi}

"Populasi adalah "obyek yang akan diteliti dalam suatu penelitian" (Onsardi, 2019). Populasiadalah orang atau keadaan yang paling tidak memiliki satu karateristik umum yang sama" (Furqon, 1997). Menurut Sugiyono (2008) "Populasi adalah wilayah generalisasi yang terdiri atas obyek / subyek yang mempunyai kualitas dan karakteristik tertentu yang ditetapkan oleh peneliti untuk

dipelajari dan kemudian ditarik kesimpulannya". Menurut Arikunto (2006) "Populasi adalah keseluruhan subyek penelitian”. Sedangkan menurut Sutrisno 
Hadi (2002) yang dimaksud dengan "populasi adalah Semua individu untuk siapa kenyataan-kenyataan yang diperoleh dari sampel itu hendak digeneralisasikan. Populasi pada penelitian ini bersifat infinite (tidak diketahui)". Populasi dari penelian ini adalah seluruh konsumen Nick Coffe Bengkulu yang berkunjung atau melakukan transaksi.

\subsubsection{Sampel}

Sugiyono (2007) "Sampel adalah bagian dari jumlah dan karakteristik yang dimiliki oleh populasi”. Populasi adalah bagian dari sampel yang reprentatif (Onsardi, 2018, Asmawi, 2017, Anjani, 2019) Teknik pengambilan sampel yang digunakan dalam penelitian ini adalah menggunakan metode non probability sampling yaitu accidental sampling. Dalam pengambilan sampel dilakukan teknik pengambilan sampel yaitu dengan accidental sampling. Menurut Sugiyono (2008) "Accidental adalah pengambilan sampel dari setiap invidu yang dijumpai secara kebetulan oleh peneliti, yaitu siapa saja yang secara keseluruhan / Accidental bertemu dengan peneliti dapat digunakan sebagai sampel, bila dipandang orang yang kebetulan ditemui cocok sebagai sumber data”. Dikarenakan jumlah populasinya tidak diketahui secara pasti maka untuk menentukan besarnya sampel digunakan rumus unknown populations (Frendy, 2011) sebagai berikut:

$$
n=\left[\frac{Z a / 2 \sigma}{e}\right] 2
$$

Keterangan :

$\mathrm{n}=$ ukuran sampel

$\mathrm{Z}=$ tingkat keyakinan sampel yang dibutuhkan dalam penelitian (pada $\alpha=5 \%$ atau derajat keyakinan ditentukan 95\% maka $\mathrm{Z}=1,96$ ) 
$\mu=$ margin of error, tingkat kesalahan yang dapat ditolerir (ditentukan 10\%) perhitungan :

$$
\begin{aligned}
& n=\left[\frac{Z a / 2 \sigma}{e}\right] 2 \\
& n=\left[\frac{(1,96) \cdot(0,25)}{0,05}\right] 2 \\
& n=96,04
\end{aligned}
$$

Berdasarkan perhitungan sampel tersebut peneliti yakin dengan tingkat kepercayaan $95 \%$ bahwa sampel random berukuran 96,04. Melihat hasil tersebut maka untuk memudahkan penghitungan data, peneliti membulatkan jumlah sampel menjadi 96 orang. Sampel pada penelitian ini konsumen Nick Coffe yang di jumpai oleh peneliti pada saat melakukan proses penelitian.

\subsection{Teknik pengumpulan data}

Untuk menjawab masalah dan menjawab hipotesis yang diajukan dalam penelitian, di perlukan data yang valid. Ada tiga data yang digunakan dalam penelitian yakni:

1. Observasi

Observasi merupakan suatu proses yang kompleks, suatu proses yang tersusun dari berbagai proses biologis dan psikologis. Teknik ini digunakan apabila penelitian berkenaan dengan perilaku manusia, proses kerja, gejalagejala, dan bila responden yang diamati tidak terlalu besar Sugiyono (2013). Obeservasi dilakukan untuk mengetahui keadaan konsumen yang sedang berkunjung di Nick Coffe Bengkulu.

2. Dokumentasi 
Menurut Sugiyono (2003), “dokumentasi adalah mencari dan mengumpulkan data mengenai hal-hal atau variabel yang berupa catatan, transkip, buku, majalah, agenda, notulen rapat dan sebagainya”. Dalam penelitian sosial, dokumentasi berfungsi memberikan data atau informasi yang digunakan sebagai data pendukung atau pelengkap bagi data primer yang diperoleh melalui observasi. Teknik dokumentasi digunakan untuk mengumpulkan data terkait dengan kualitas produk, pelayanan, dan kepuasan pelanggan.

3. Kuesioner

"Kuesioner merupakan teknik pengumpulan data yang dilakukan dengan cara memberi seperangkat pernyataan atau pertanyaan tertulis kepada responden untuk dijawab" (Sugiyono, 2009). Angket ini bersifat tertutup dan digunakan untuk mengukur variabel.

Penelitian ini menggunakan skala ordinal, menurut Sugiyono (2010:98) adalah "skala ordinal adalah skala pengukuran yang tidak hanya menyatakan kategori, tetapi juga menyatakan peringkat construct yang diukur”.

Tabel 3. 1 Skala Ordinal

\begin{tabular}{|c|c|c|}
\hline No & Pernyataan & Bobot \\
\hline 1 & Sangat Setuju (SS) & 5 \\
\hline 2 & Setuju (S) & 4 \\
\hline 3 & Normal (N) & 3 \\
\hline 4 & Tidak Setuju (TS) & 2 \\
\hline 5 & Sangat Tidak Setuju (STS) & 1 \\
\hline
\end{tabular}


Tabel 3.2 Kisi - Kisi Kuesioner

\begin{tabular}{|c|c|c|c|c|}
\hline No & Variabel & Indikator & Butir & $\sum$ \\
\hline 1. & Promosi & $\begin{array}{l}\text { 1. Periklanan } \\
\text { 2. Promosi Penjualan } \\
\text { 3. Personal selling } \\
\text { 4. Publisitas } \\
\text { 5. Pemasaran langsung dan } \\
\text { iteraksi }\end{array}$ & $\begin{array}{l}1-2 \\
3-4 \\
5-6 \\
7-8 \\
9-10\end{array}$ & $\begin{array}{l}2 \\
2 \\
2 \\
2 \\
2\end{array}$ \\
\hline & & & Jumlah & 10 \\
\hline 2. & Atribut Toko & $\begin{array}{l}\text { 1. Lokasi } \\
\text { 2. Harga } \\
\text { 3. Kualitas Barang } \\
\text { 4. Keragaman Barang } \\
\text { 5. Pelayanan } \\
\text { 6. Promosi } \\
\text { 7. Fasilitas fisik } \\
\text { 8. Atmosfer } \\
\text { 9. Pelayanan Purna Jual }\end{array}$ & $\begin{array}{l}11-13 \\
14-16 \\
17-19 \\
20-22 \\
23-25 \\
26-28 \\
29-31 \\
32-34 \\
35-37\end{array}$ & $\begin{array}{l}3 \\
3 \\
3 \\
3 \\
3 \\
3 \\
3 \\
3 \\
3\end{array}$ \\
\hline & & & Jumlah & 27 \\
\hline 3. & Inovasi Produk & $\begin{array}{l}\text { 1. Prodak baru bagi dunia } \\
\text { 2. Lini produk baru }\end{array}$ & $\begin{array}{l}38-39 \\
40-41\end{array}$ & $\begin{array}{l}2 \\
2\end{array}$ \\
\hline
\end{tabular}




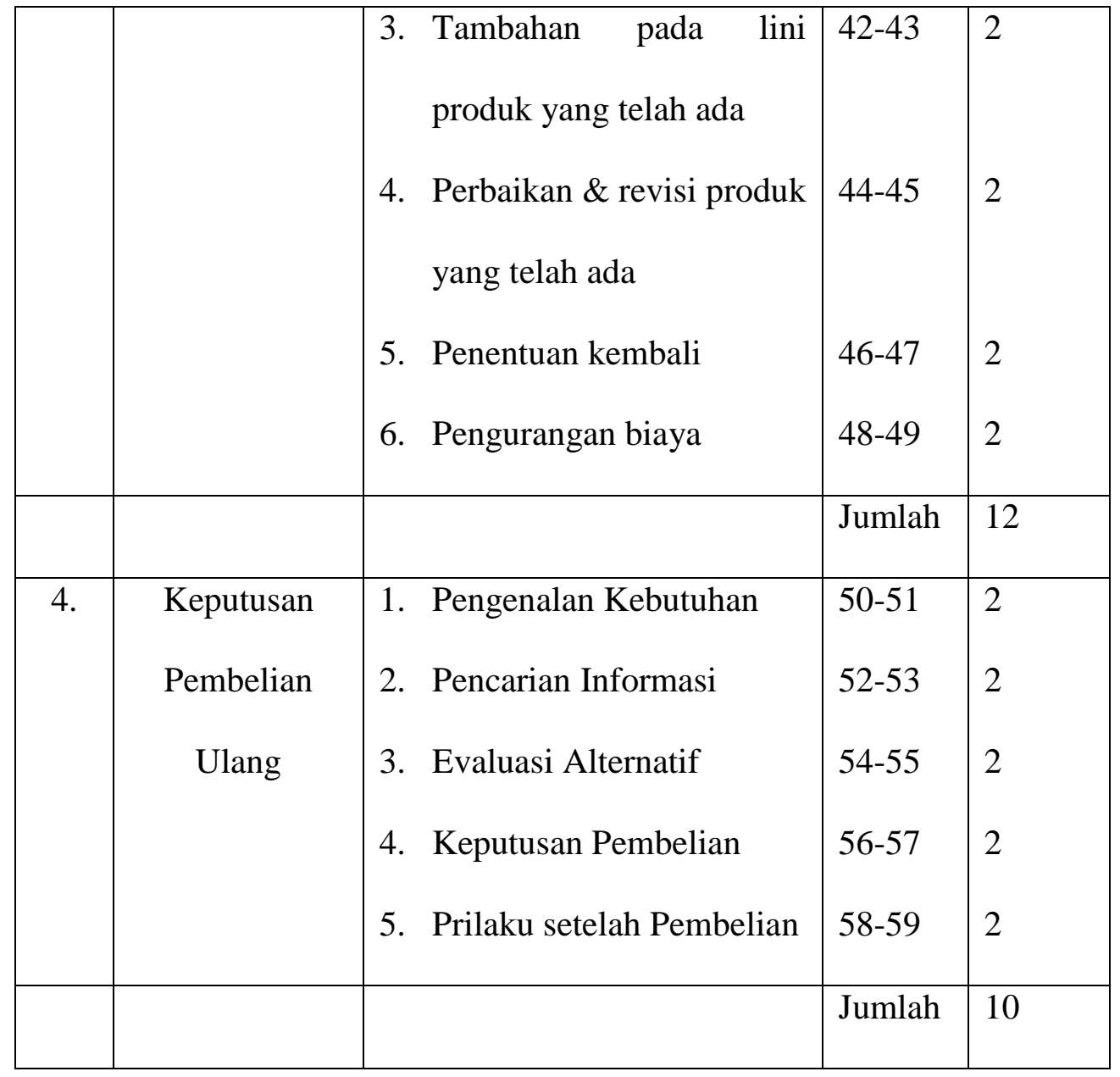

\subsubsection{Uji Instrumen}

Uji instrumen digunakan untuk menguji kuesioner yang telah di buat, dalam penelitian ini uji instrumen yang digunakan ada dua, yaitu uji validitas instrumen dan uji reliabilitas instrumen. Dengan menggunakan instrumen yang valid dan reliabel dalam pengumpulan data maka diharapkan hasil penelitian akan menjadi valid dan reliabel. Uji ini ditentukan dengan sampel khusus sejumlah 20 orang responden diluar sampel penelitian yaitu Konsumen pada Nick Coffe di Kota Bengkulu. Data yang telah terkumpul diuji dengan menggunakan bantuan program SPSS for Windows versi 23. 
1. Uji Validitas Instrumen

Uji validitas digunakan untuk mengukur sah atau valid tidaknya suatu kuesioner. Suatu kuesioner dikatakan valid jika pertanyaan pada kuesioner mampu untuk mengungkapkan sesuatu yang akan diukur oleh kuesioner tersebut. Pengukuran validitas dalam penelitian ini dilakukan dengan menggunakan coefficient corelation pearson yaitu dengan menghitung korelasi antara skor masing-masing butir pertanyaan dengan total skor (Imam Ghozali, 2005). Uji validitas dapat dilakukan dengan membandingkan nilai $\mathrm{r}$ hitung (Correlated Item Total Correlation) dengan $\mathrm{r}$ tabel untuk degree of freedom $(\mathrm{df})=\mathrm{n}-\mathrm{k}$, dalam hal ini $\mathrm{n}$ adalah jumlah sampel $\mathrm{k}$ adalah jumlah variabel independen.

Hasil $\mathrm{r}$ hitung $>\mathrm{r}$ tabel $=$ valid

Hasil $r$ hitung $<\mathrm{r}$ tabel $=$ tidak valid

Hasil validitas dapat dilihat pada output Alpha Cronbach pada kolom Corrected Item - Total Correlation. Bandingkan nilai Correlated Item Total Correlation dengan hasil perhitungan $r$ tabel. Jika $r$ hitung $>r$ tabel dan nilai positif, maka butir pernyataan atau indikator tersebut dinyatakan valid (Imam Ghozali, 2005).

2. Uji Reliabilitas Instrumen

Uji reliabilitas adalah pengujian untuk mengukur suatu kuesioner yang merupakan indikator dari variabel atau konstruk. Suatu kuesioner dikatakan 
reliabel atau handal jika jawaban seseorang terhadap pernyataan adalah konsisten atau stabil dari waktu ke waktu. Pengukuran reliabilitas dalam penelitian ini dilakukan dengan cara one shot (pengukuran sekali saja). Disini pengukuran hanya dilakukan dengan pertanyaan lain atau mengukur korelasi antar jawaban pertanyaan. Alat untuk mengukur reliabilitas adalah Alpha Cronbach. Menurut Imam Ghozali (2005) suatu variabel dikatakan reliabel, apabila :

Hasil Alpha Cronbach $>0,60=$ reliable

Hasil Alpha Cronbach $<0,60=$ tidak reliable

\subsection{Teknis Analisis Data}

Analisis data adalah suatu keadaan untuk meneliti, memeriksa, mempelajari, membandingkan, data yang ada dan membuat indepretasi yang diperlukan. Selain itu, analisi data dapat digunakan untuk mengidentifikasi ada tidaknya masalah.

\subsubsection{Teknik Analisis Deskriptif}

Bagian analisis ini akan membahas mengenai bentuk tanggapan responden terhadap kuesioner yang disebarkan kepada responden. Dari sebaran jawaban responden selanjutnya Akan diperoleh satu kecenderungan jawaban responden terhadap jawaban masing-masing variabel akan didasarkan pada nilai rata-rata skor yang selanjutnya akan dikonfirmasikan Pada tabel interval,Adapun perhitungan rata-rata dari responden menggunakan rumus sebagai berikut :

$$
\mathbf{X}=\frac{\sum x}{N}
$$

Keterangan : 
$\mathrm{X}=$ Angka rata - rata

$\mathrm{N}=$ Jumlah skor

$\sum \mathrm{x}=$ Nilai responden

Hasil rata-rata jawaban responden tersebut dikonfirmasikan pada interval penelitian menetapkan tentang interval penelitian tersebut. terhitung berdasarkan rumus sebagai berikut:

$$
\begin{aligned}
& \mathrm{I}=\frac{R}{k} \\
& \text { Keterangan : } \\
& \mathrm{I}=\text { Interval } \\
& \mathrm{R}=\text { Range (nilai tertinggi-nilai terendah) } \\
& \mathrm{K}=\text { Jumlah kategori } \\
& =\frac{5-1}{5}=0.8
\end{aligned}
$$

Setelah besarnya interval diketahui, kemudian dibuat rentan skala sehingga dapat ditentukan kriteria penelitian persepsi responden terhadap variabel-variabel penelitian sebagai berikut :

Tabel 3.3

Tanggapan Responden Terhadap Variabel

\begin{tabular}{|c|c|}
\hline Intervak Koefisien & Tingkat Hubungan \\
\hline $4,20-5,00$ & Sangat Baik \\
$3,40-4,19$ & Baik \\
$2,60-3.39$ & Cukup Baik \\
$1,80-2,59$ & Tidak Baik \\
$1,00-1,79$ & Sangat Tidak Baik \\
\hline
\end{tabular}

Sumber : (Cooper dan Emory, 2016) 


\subsubsection{Uji Asumsi Klasik}

Untuk menguji kelayakan model regresi yang digunakan, maka harus terlebih dahulu memenuhi uji asumsi klasik. Uji asumsi klasik dalam penelitian ini terdiri dari uji normalitas, uji linearitas, uji multikolineritas, dan uji heteroskedastisitas.

1. Normalitas

Menurut Suliyanto (2005) uji normalitas dimaksudkan untukmengetahui apakah residual yang diteliti berdistribusi normal atau tidak. Tujuan uji normalitas adalah untuk menguji apakah dalam sebuah model regresi, variabel dependen, variabel independen atau ketiganya mempunyai distribusi normal atau mendekati normal. Uji normalitas dilakukan untuk mengetahui apakah data peneliti ketiga variable terdistribusi secara normal. Uji normalitas ini dilakukan dengan menggunakan uji one sample Kolmogorov-Smirnov dengan bantuan SPSS for Windows versi 23. Data dikatakan terdistribusi normal jika nilai $\mathrm{p}>0,05$.

2. Uji Multikolinearitas

Pengujian multikolinearitas bertujuan untuk menguji apakah model regresi yang ditemukan adanya korelasi antara variabel bebas. Model regresi yang baik seharusnya tidak terjadi korelasi siantara variabel bebas (Ghozali, 2011). Untuk menguji multikolinieritas dengan cara melihat nilai VIF masing-masing variabel independen, jika nilai VIF $<10$, maka dapat disimpulkan data bebas dari gejala multikolinieritas. 
3. Uji Heteroskedastisitas

Uji heteroskedastisitas bertujuan menguji apakah dalam model regresi terjadi ketidaksamaan variance dari residual satu pengamatan ke pengamatan lain (Ghzali, 2006). Jika varian dari residual dari satu pengamatan ke pengamatan yang lain tetap, maka disebut homoskedastisitas dan jika berbeda disebut heteroskedastisitas. Model regresi yang baik adalah yang homoskedastisitas atau tidak terjadi heteroskedastisitas. Cara mendektesinya dengan cara melihat grafik antara nilai prediksi variabel terikat (ZPRED) dengan residualnya (SRESID). Deteksi ada tidaknya heteroskedastisitas dapat dilakukan dengan melihat ada tidaknya pola tertentu pada grafik antara SRESID dan ZPRED dimana sumbu Y adalah Y yang telah diprediksikan, dan sumbu $\mathrm{X}$ adalah residual ( $\mathrm{Y}$ prediksi- $\mathrm{Y}$ sesungguhnya) yang telah distudentized analisisnya:

1) Jika ada pola tertentu seperti titik- titik yang ada membentuk pola tertentu yang teratur (bergelombang,melebar kemudian menyempit)maka mengidentifikasikan telah terjadi heteroskedastisitas.

2) Jika tidak ada pola yang jelas serta titik- titik yang menyebar di atas dan dibawah angka nol pada sumbu Y, maka tidak terjadi heteroskedastisitas.

\subsubsection{Analisi Regresi Berganda}

Analisis regresi berganda digunakan untuk mengetahui pengaruh antara Promosi (X1), Atribut Toko (Store Attributes) (X2), dan Inovasi Produk (X3) terhadap Keputusan Pembelian Ulang (Y). 
Selain itu untuk mengetahui sejauh mana besarnya pengaruh antara variabel bebas dan variabel terikat (Sutrisno Hadi, 1999). Adapun bentuk umum persamaan regresi berganda yang digunakan dalam penelitian ini adalah sebagai berikut:

$Y=a+b_{1} X_{1}+b_{2} X_{2}+b_{3} X_{3}+e$

Dimana:

$\mathrm{Y}=$ Keputusan Pembelian Ulang

$\mathrm{a}=$ Konstanta

$\mathrm{X} 1=$ Promosi

$\mathrm{X} 2$ = Atribut Toko (Store Attributes)

X3 = Inovasi Produk

b1,b2,b3 = Besaran koefisien regresi dari masing-masing variable

$\mathrm{e}=$ error

\subsubsection{Analisis Koefisien Determinasi $\left(\mathbf{R}^{2}\right)$}

Koefisien determinasi $\left(\mathrm{R}^{2}\right)$ digunakan untuk mengetahui sampai seberapa besar presentase variasi variable bebas pada model dapat diterangkan oleh variable terikat (Gujarati, 1995). Koefisien determinasi $\left(\mathrm{R}^{2}\right)$ dinyatakan dalam presentase yang nilainya berkisar antara $0<\mathrm{R}^{2}<1$. Nilai $\mathrm{R}^{2}$ yang kecil berarti kemampuan variable-variabel independen.

Dalam menjelaskan variasi variable dependen amat terbatas. Nilai yang mendekati satu berarti variable-variabel independen memberikan hampir semua informasi yang dibutuhkan untuk memprediksi variasi variable dependen. Secara umum koefisien determinasi untuk data silang (Crossection) relative rendah 
karena adanya variasi yang besar antara masing-masing pengamatan, sedangakan untuk data runtun waktu (Time series) biasanya mempunyai nilai koefisien determinasi yang tinggi.

Kelemahan mendasar pada pengguna koefisien determinasi adalah bias terhadap jumlah variable independen, maka $\mathrm{R}^{2}$ pasti akan meningkat tanpa melihat apakah variable tersebut berpengaruh secara signifikan terhadap variable dependent. Oleh karena itu, banyak penelitian yang menganjurkan untuk menggunakan Adjusted $\mathrm{R}^{2}$ untuk mengevaluasi model regresi karena Adjusted $\mathrm{R}^{2}$ dapat naik atau turun apabila satu variable independen ditambahkan ke dalam model (Ghozali, 2009). Dengan demikian, pada penelitian ini menggunakan nilai Adjusted $\mathrm{R}^{2}$ untuk mengevaluasi model regresi.

\subsubsection{Uji Hipotesis}

Uji hipotesis bertujuan untuk mengetahui apakah ada tidaknya pengaruh yang signifikan antara variabel independen (Promosi, Atribut Toko (Store Attributes), dan Inovasi Produk) terhadap variabel dependen (keputusan Pembelian Ulang) baik secara parsial maupun simultan.

1. Uji- t (parsial)

Uji hipotesis ini dilakukan dengan cara membandingkan nilai t hitung dengan nilai $\mathrm{t}$ tabel tingkat keyakinan $95 \%$ atau $\alpha=0,05$. Uji $-\mathrm{t}$ digunakan untuk menguji apakah variabel bebas mempunyai pengaruh yang signifikan terhadap nilai variabel terikat dengan rumus hipotesis sebagai berikut :

$$
\mathrm{t}=\frac{b i}{S b i} \quad \text { Sugiyono (2013) }
$$


Keterangan :

$\mathrm{t}=$ nilai $\mathrm{t}$ hitung

bi $=$ koefisien regresi

sbi $=$ standar error

Dengan langkah pengujian sebagai berikut :

a. Perumusan Hipotesis

Ho: Promosi, Atribut Toko (Store Attributes), dan Inovasi Produk tidak mempunyai pengaruh signifikan secara parsial terhadap keputusam Pembelian Ulang pada Nick Coffe Bengkulu.

Ha: Promosi, Atribut Toko (Store Attributes), dan Inovasi Produk mempunyai pengaruh signifikan secara parsial terhadap keputusam Pembelian Ulang pada Nick Coffe Bengkulu.

b. Kriteria Pengujian

1) Jika $t_{\text {sign }}<(\alpha=0,05)$ Ho ditolak, Ha diterima. Artinya secara parsial ada pengaruh signifikan variabel Promosi $\left(\mathrm{X}_{1}\right)$, Atribut Toko (Store Attributes) $\left(\mathrm{X}_{2}\right)$, dan Inovasi Produk terhadap keputusan Pembelian Ulang (Y).

2) Jika $t_{\text {sign }}>(\alpha=0,05) \mathrm{H}_{\mathrm{O}}$ diterima, Ho ditolak. Artinya secara parsial tidak ada pengaruh signifikan variabel Promosi $\left(\mathrm{X}_{1}\right)$, Atribut Toko (Store Attributes) $\left(\mathrm{X}_{2}\right)$, dan Inovasi Produk terhadap keputusan Pembelian Ulang (Y).

Nilai $t_{\text {sign }}$ dari uji $\mathrm{t}$ dapat dilihat dari hasil pengelolaan dari program SPSS for Windows versi 23. 


\section{Uji-F (simultan)}

Uji-f digunakan untuk melihat secara bersama-sama signifikansi pengaruh variabel bebas yaitu Promosi $\left(\mathrm{X}_{1}\right)$, Atribut Toko (Store Attributes) $\left(\mathrm{X}_{2}\right)$, dan Inovasi Produk $\left(\mathrm{X}_{3}\right)$ terhadap variabel terikatnya yaitu keputusan Pembelian Ulang (Y). Pada taraf keyakinan $95 \%$ atau $\alpha=0,05$. Dengan rumus sebagai berikut :

F.test $=\frac{R^{2} /(k-1)}{(1-R) /(n-k)}$

(Sugiyono, 2013)

Adapun prosedur pengujian hipotesis statistiknya menurut Wirawan (2002) adalah sebagai berikut:

\section{Perumusan Hipotesis}

Ho: tidak ada pengaruh yang signifikan secara bersama-sama antara Promosi, Atribut Toko (Store Attributes), dan Inovasi Produk terhadap keputusam Pembelian Ulang pada Nick Coffe Bengkulu.

Ha: ada pengaruh yang signifikan secara bersama-sama antara Promosi, Atribut Toko (Store Attributes), dan Inovasi Produk terhadap keputusam Pembelian Ulang pada Nick Coffe Bengkulu.

\section{Kriteria Pengujian}

Selanjutnya hasil hipotesis di uji dengan ketentuan sebagai berikut :

1) Jika $\mathrm{f}_{\text {sign }}<(\alpha=0,05)$ Ho ditolak, Ha diterima berarti secara bersamaan ada pengaruh variabel Promosi, Atribut Toko (Store Attributes), dan Inovasi Produk terhadap keputusam Pembelian Ulang. 
2) Jika $\mathrm{f}_{\text {sign }}>(\alpha=0,05)$ Ho diterima, Ha ditolak berarti tidak ada pengaruh secara bersamaan variabel Promosi, Atribut Toko (Store Attributes), dan Inovasi Produk terhadap keputusam Pembelian Ulang.

Nilai $\mathrm{f}_{\text {sign }}$ dari uji $\mathrm{F}$ dapat dilihat dari hasil pengelolaan dari program SPSS for Windows versi 23.

\section{BAB IV \\ HASIL DAN PEMBAHASAN}

\subsection{Deskripsi Nick Coffe Bengkulu}

Nick Coffe adalah salah satu Cafe yang baru berdiri di Kota Bengkulu. Nick Coffe berdiri sejak tanggal 10 Maret 2019 yang dimiliki oleh Nichel Alfathah Saputra, dialah remaja yang baru saja duduk di bangku sekolah kelas 1 SMP, tepatnya di Sekolah Alam Mahira Kota bengkulu.

Nick Coffe yang terletak di jalan Ciliwung Bawah No. 33 RW.01 kelurahan Lempuing sekang memiliki pengunjung yang cukup ramai. Nick memang suka kopi, awalnya dia Penasaran, melihat dan akhirnya diajak oleh kakak angkatnya Untuk belajar kelas - kelas barista di Jakarta. Setelah belajar Nick menyalurkan atau menerapkan ilmu yang iya peroleh tersebut untuk di nikmati orang lain.

Konsumen yang berdatangan pun beragam mulai dari anak muda sampai dengan orang tua, tetapi yang lebih mendominasi adalah anak muda. Dengan hanya sekedar bercengkrama, bercanda gurau, bermain games, dan bernyanyi bersama, dengan ditemani secangkir kopi atau menu yang lain membuat para penikmat kopi merasa lebih enjoy, dan rileks. Pelayanan yang diberikan kepada 
konsumen juga sangat baik terlihat dari keramahan karyawan dalam menyapa konsumen yang datang ke cafe tersebut.

Disini juga tidak hanya menyediakan Coffe, bagi mereka yang tidak terlalu menyukai kopi juga tersedia menu lain seperti Tea, Thai Tea, Lemon Tea, dan masih banyak yang lain. Sedangkan bagi pencinta Coffe tersedia Espresso, Americano, Mocha, Latte, Cappucino, kopi susu jadul, Coffe Lemonade, Caramel Mattaciato,dll. Coffe disini asli Coffe Bengkulu yang di pakai adalah Coffe Robusta Kepahiang, sedangkan Arabika nya sendiri dari Curup, dan Snack nya hanya tersedia kentang dan juga donat.

\subsection{Karakteristik Responden}

Responden yang menjadi subjek pada penelitian ini adalah konsumen Nick Coffe di kota Bengkulu. Dari hasil pengumpulan data melalui koesioner terhadap 96 orang yang dijadikan responden penelitian, maka dapat diketahui karakteristik responden berdasarkan jenis kelamin, usia, dan pendidikan terakhir.

\section{Karakteristik Responden Berdasarkan Jenis Kelamin}

Jumlah responden berdasarkan jenis kelamin yang ada pada Konsumen Nick Coffe di Kota Bengkulu dapat dilihat pada tabel 4.1

Tabel 4. 1

Karakteristik Responden Berdasarkan jenis Kelamin

\begin{tabular}{|c|c|c|}
\hline Jenis Kelamin & Frekuensi & Persentase \\
\hline Laki-laki & 54 & $56,25 \%$ \\
\hline Perempuan & 42 & $43,75 \%$ \\
\hline Total & 96 & 100 \\
\hline
\end{tabular}

Sumber: Data yang diolah 2020 
Berdasarkan tabel di atas diketahui karakteristik responden berdasarakan jenis kelamin laki-laki sebanyak 54 orang responden atau $56.25 \%$, kemudian jumlah responden perempuan sebanyak 42 orang responden atau $43.75 \%$. Dari data tersebut menyatakan bahwa konsumen Nick Coffe lebih banyak laki-laki dari pada perempuan.

\section{Karakteristik Responden Berdasarkan Usia}

Jumlah responden berdasarkan usia yang ada pada Konsumen Nick Coffe di Kota Bengkulu dapat dilihat pada tabel 4.2

Tabel 4. 2

Karakteristik Responden Berdasarkan Usia

\begin{tabular}{|c|c|c|}
\hline Usia & Frekuensi & Persentase \\
\hline $11-20$ & 33 & 34,4 \\
\hline $21-30$ & 37 & 38,5 \\
\hline $31-40$ & 14 & 14,6 \\
\hline$>41$ & 12 & 12,5 \\
\hline Total & 96 & 100 \\
\hline
\end{tabular}

Sumber: Data yang diolah 2020

Berdasarkan tabel 4.2 Diketahui karakteristik responden berdasarkan usia yang paling mendominasi usia 21 - 30 responden dengan persentase $38.5 \%$. Dari data tersebut dapat disimpulkan bahwa rata-rata Konsumen pada Nick Coffe di Kota Bengkulu berada kisaran umur 21 - 30 tahun.

\section{Karakteristik Responden Berdasarkan Pekerjaan}

Jumlah responden berdasarkan pekerjaan yang ada pada Nick Coffe di Kota Bengkulu dapat dilaihat pada tabel 4.3 
Tabel 4.3

Karakteristik Responden Berdasarkan Pekerjaan

\begin{tabular}{|l|c|c|}
\hline \multicolumn{1}{|c|}{ Pekerjaan } & Frekuensi & Persentase \\
\hline Pelajar/Mahasiswa & 33 & 34,4 \\
\hline Karyawan Swasta/PNS & 15 & 15,6 \\
\hline Guru/Dosen & 10 & 10.4 \\
\hline Wirausaha & 22 & 22.9 \\
\hline Lain-Lain & 16 & 16,7 \\
\hline Total & 96 & 100 \\
\hline
\end{tabular}

Sumber: Data yang diolah 2020

Berdasarkan tabel 4.3 diketahui karakteristik responden berdasarkan pekerjaan yang paling mendominasi Pelajar/Mahasiswa sebanyak 33 responden dengan persentase $34.4 \%$. Dari data tersebut dapat disimpulkan bahwa rata-rata konsumen Nick Coffe di Kota Bengkulu didominasi dengan Pelajar/Mahasiswa.

\section{Karakteristik Responden Berdasarkan Pendidikan}

Jumlah responden berdasarkan Pendidikan yang ada pada konsumen Nick Coffe di Kota Bengkulu dapat dilaihat pada tabel 4.4

Tabel 4. 4

Karakteristik Responden Berdasarkan Pendidikan

\begin{tabular}{|l|c|c|}
\hline \multicolumn{1}{|c|}{ Pendidikan } & Frekuensi & Persentase \\
\hline SMA & 38 & 39,6 \\
\hline DIPLOMA & 22 & 22,9 \\
\hline SARJANA & 25 & 26,1 \\
\hline PASCA SARJANA & 11 & 11,4 \\
\hline TOTAL & 96 & 100 \\
\hline
\end{tabular}

Sumber: Data yang diolah 2020 
Berdasarkan tabel 4.4 diketahui karakteristik responden berdasarkan Pendidikan yang paling mendominasi SMA sebanyak 38 responden dengan persentase $39.6 \%$. Dari data tersebut dapat disimpulkan bahwa rata-rata konsumen Nick Coffe di Kota Bengkulu didominasi dengan Pendidikan SMA.

\section{Karakteristik Responden Berdasarkan Asal Kota}

Jumlah responden berdasarkan Asal Kota yang ada pada konsumen Nick Coffe di Kota Bengkulu dapat dilaihat pada tabel 4.5

Tabel 4.5

Karakteristik Responden Berdasarkan Asal Kota

\begin{tabular}{|l|c|c|}
\hline \multicolumn{1}{|c|}{ Asal } & Frekuensi & Persentase \\
\hline Bengkulu & 64 & 66,7 \\
\hline Dan lain-lain & 32 & 33,3 \\
\hline Total & 96 & 100 \\
\hline
\end{tabular}

Sumber: Data yang diolah 2020

Berdasarkan tabel 4.5 diketahui karakteristik responden berdasarkan Asal Kota yang paling mendominasi dari Bengkulu sebanyak 64 responden dengan persentase $66.7 \%$. Dari data tersebut dapat disimpulkan bahwa rata-rata konsumen Nick Coffe di Kota Bengkulu didominasi dengan Asal Bengkulu.

\subsection{Uji Instrumen}

\subsubsection{Uji Validitas}

Pada uji validitas instrumen yang akan dilakukan pada setiap instrumen penelitian memperoleh hasil jika $\mathrm{r}$ positif, serta $\mathrm{r} \geq 0,30$ maka pernyataan tersebut 
valid, dan jika $r<0,30$ maka item pernyataan tidak valid (Sugiyono 2013). Dapat dilihat pada tabel 4.6 Dari setiap item pernyataan

Tabel 4.6

Hasil Uji Validitas Instrumen

\begin{tabular}{|c|c|c|c|c|}
\hline Variabel & Indikator & $\begin{array}{l}\text { Item } \\
\text { Perny } \\
\text { ataan }\end{array}$ & $\begin{array}{c}\text { Corrected Item } \\
\text { Pernyataan Total } \\
\text { Correlation }\end{array}$ & Keterangan \\
\hline \multirow{10}{*}{ Promosi } & \multirow{2}{*}{ Periklanan } & 1 & 0,581 & Valid \\
\hline & & 2 & 0,608 & Valid \\
\hline & \multirow{2}{*}{$\begin{array}{l}\text { Promosi } \\
\text { Penjualan }\end{array}$} & 3 & 0,318 & Valid \\
\hline & & 4 & 0,452 & Valid \\
\hline & \multirow{2}{*}{$\begin{array}{c}\text { Personal } \\
\text { Selling }\end{array}$} & 5 & 0,476 & Valid \\
\hline & & 6 & 0,401 & Valid \\
\hline & \multirow{2}{*}{ Publisitas } & 7 & 0,374 & Valid \\
\hline & & 8 & 0,563 & Valid \\
\hline & \multirow{2}{*}{$\begin{array}{l}\text { Pemasaran } \\
\text { Langsung } \\
\text { dan } \\
\text { iteraksi }\end{array}$} & 9 & 0,352 & Valid \\
\hline & & 10 & 0,485 & Valid \\
\hline \multirow{10}{*}{$\begin{array}{l}\text { Atribut } \\
\text { Toko } \\
\text { (Store } \\
\text { Attributes) }\end{array}$} & \multirow{3}{*}{ Lokasi } & 11 & 0,486 & Valid \\
\hline & & 12 & 0,485 & Valid \\
\hline & & 13 & 0,467 & Valid \\
\hline & \multirow{3}{*}{ Harga } & 14 & 0,507 & Valid \\
\hline & & 15 & 0,630 & Valid \\
\hline & & 16 & 0,519 & Valid \\
\hline & \multirow{3}{*}{$\begin{array}{c}\text { Kualitas } \\
\text { Barang }\end{array}$} & 17 & 0,358 & Valid \\
\hline & & 18 & 0,697 & Valid \\
\hline & & 19 & 0,440 & Valid \\
\hline & Keragaman & 20 & 0,524 & Valid \\
\hline
\end{tabular}




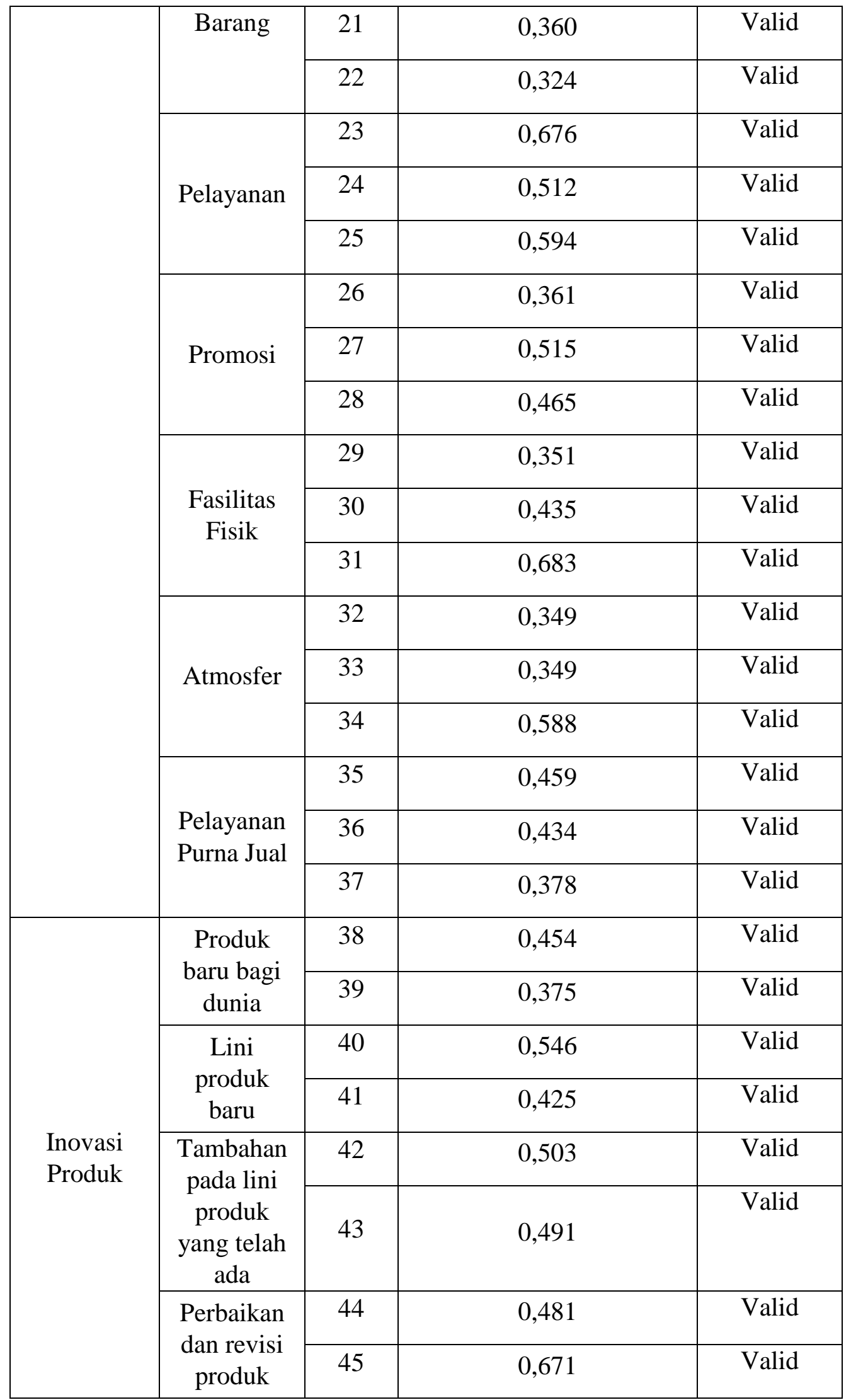




\begin{tabular}{|c|c|c|c|c|}
\hline & $\begin{array}{c}\text { yang telah } \\
\text { ada } \\
\end{array}$ & & & \\
\hline & Penentuan & 46 & 0,487 & Valid \\
\hline & Kembali & 47 & 0,461 & Valid \\
\hline & Penourano & 48 & 0,458 & Valid \\
\hline & an biaya & 49 & 0,461 & Valid \\
\hline & Pengenalan & 50 & 0,484 & Valid \\
\hline & kebutuhan & 51 & 0,425 & Valid \\
\hline & Pencarian & 52 & 0,548 & Valid \\
\hline & informasi & 53 & 0,486 & Valid \\
\hline Keputusan & Fvaluasi & 54 & 0,355 & Valid \\
\hline $\begin{array}{l}\text { Ulang } \\
\text { Uembentan }\end{array}$ & alternatif & 55 & 0,570 & Valid \\
\hline & Kenutucan & 56 & 0,519 & Valid \\
\hline & pembelian & 57 & 0,377 & Valid \\
\hline & Prilaku & 58 & 0,585 & Valid \\
\hline & pembelian & 59 & 0,452 & Valid \\
\hline
\end{tabular}

Sumber: Output SPSS 23 yang diolah, 2020

Dari tabel diatas dapat dilihat nilai Corrected Item Total Corelation atau nilai untuk masing-masing variabel $>\mathrm{r}$ tabel $(0.30)$. ini menunjukkan bahwa item dari setiap pertanyaan kuesioner masing-masing variabel tersebut adalah valid dan layak untuk digunakan dalam penelitian ini. Artinya item dari setiap pernyataan tersebut mampu mengukur dan menjelaskan variabelnya secara tepat. 


\subsubsection{Uji Reliabilitas}

Pada uji reliabilitas yang dilakukan terhadap setiap instrumen penelitian memperoleh hasil bahwa nilai Cronbach's Alpha pada setiap instrumen penelitian dikatakan reliabel (Imam Ghozali ,2005), apabila :

Hasil Alpha Cronbach $>0,60=$ reliable

Hasil Alpha Cronbach $<0,60=$ tidak reliable

Tabel 4. 7

\section{Hasil Uji Reliabilitas}

\begin{tabular}{|c|c|c|c|}
\hline No & Variabel & Cronbach's Alpha & Keterangan \\
\hline 1 & Promosi & 0,727 & Reliabel \\
\hline 2 & $\begin{array}{c}\text { Atribut Toko (Store } \\
\text { Attributes) }\end{array}$ & 0,740 & Reliabel \\
\hline 3 & Inovasi Produk & 0,735 & Reliabel \\
\hline 4. & $\begin{array}{c}\text { Keputusan Pembelian } \\
\text { Ulang }\end{array}$ & 0,732 & Reliabel \\
\hline
\end{tabular}

Sumber: Output SPSS 23 yang diolah, 2020

Tabel diatas menunjukkan hasil pengujian terhadap masing-masing variabel, dapat disimpulkan bahwa semua variabel menunjukkan sebagai suatu ukuran yang reliabel, karena masing-masing variabel memiliki Cronbach's Alpha > 0.60. Hal ini berarti instrumen penelitian (kuesioner) memiliki hasil yang reliabel (konsisten) sehingga layak untuk digunakan dalam penelitian.

\subsubsection{Analisis Deskriptif}

Pada bagian ini akan disajikan data mengenai skor jawaban responden terhadap pernyataan-pernyataan kuisioner masing-masing variable penelitian yaitu 
Promosi $\left(\mathrm{X}_{1}\right)$, Atribut Toko $\left(\mathrm{X}_{2}\right)$, dan Inovasi Produk $\left(\mathrm{X}_{3}\right)$, Keputusan Pembelian Ulang (Y) pada Nick Coffe di Kota Bengkulu

\subsubsection{Tanggapan Responden Terhadap Variabel Promosi}

Hasil dari Distribusi frekuensi tanggapan responden terhadap variabel Promosi $\left(\mathrm{X}_{1}\right)$ terhadap Keputusan Pembelian Ulang pada Nick Coffe di Kota Bengkulu, berdasarkan 10 pernyataan kuesioner kepada responden sebagai berikut.

Tabel 4.8

Tanggapan Responden terhadap Promosi $\left(\mathrm{X}_{1}\right)$

\begin{tabular}{|c|l|c|c|c|c|c|c|c|}
\hline No & Pernyataan Sikap Konsumen & STS & TS & N & S & SS & Jumlah & $\begin{array}{c}\text { Rata- } \\
\text { rata }\end{array}$ \\
\hline 1. & $\begin{array}{l}\text { Periklanan } \\
\text { Iklan Nick Coffe dimedia } \\
\text { massa maupun media } \\
\text { elektronik sangat menarik }\end{array}$ & 6 & 9 & 18 & 36 & 27 & 357 & 3,72 \\
\hline $\begin{array}{l}\text { Frekuensi penayangan iklan } \\
\text { Nick Coffe termasuk sering } \\
\text { jika dibandingkan dengan iklan } \\
\text { toko ritel yang lain }\end{array}$ & 7 & 7 & 17 & 36 & 29 & 361 & 3,76 \\
\hline 3. & $\begin{array}{l}\text { Iklan Nick Coffe mampu } \\
\text { menjangkau semua kalangan }\end{array}$ & 5 & 17 & 16 & 40 & 18 & 337 & 3,51 \\
\hline 4. & $\begin{array}{l}\text { Tenaga penjual di Nick Coffe } \\
\text { berhasil meyakinkan anda } \\
\text { untuk membeli dan } \\
\text { menggunakan produk yang } \\
\text { dijual }\end{array}$ & 5 & 6 & 20 & 47 & 18 & 355 & 3,70 \\
\hline 5. & $\begin{array}{l}\text { Promosi Penjualan } \\
\text { tenaga penjual Nick Coffe } \\
\text { yang dijual }\end{array}$ & 0 & 6 & 18 & 60 & 12 & 366 & 3,81 \\
\hline & $\begin{array}{l}\text { Personal Selling } \\
\text { Apa yang dipromosikan oleh }\end{array}$ & & & & & & & \\
\hline
\end{tabular}




\begin{tabular}{|c|c|c|c|c|c|c|c|c|}
\hline 6. & $\begin{array}{l}\text { Tenaga penjual di Nick Coffe } \\
\text { tanggap terhadap keluhan dan } \\
\text { kebutuhan pelanggan }\end{array}$ & 3 & 7 & 26 & 38 & 22 & 357 & 3,72 \\
\hline & Publisitas & & & & & & & \\
\hline 7. & $\begin{array}{l}\text { Potongan harga dalam } \\
\text { pembelian produk menarik } \\
\text { perhatian anda untuk membeli } \\
\text { dan menggunakannya }\end{array}$ & 1 & 8 & 22 & 41 & 24 & 367 & 3,82 \\
\hline 8. & Hadiah yang diberikan menarik & 2 & 3 & 22 & 39 & 30 & 380 & 3,96 \\
\hline & $\begin{array}{l}\text { Pemasaran Langsung Dan } \\
\text { Interaksi }\end{array}$ & & & & & & & \\
\hline 9. & $\begin{array}{l}\text { Artikel berita mengenai produk } \\
\text { Nick Coffe yang anda baca } \\
\text { memberikan informasi yang } \\
\text { menarik kepada anda }\end{array}$ & 4 & 1 & 19 & 57 & 15 & 366 & 3,81 \\
\hline 10. & $\begin{array}{l}\text { Artikel berita mengenai produk } \\
\text { yang dijual di Nick Coffe yang } \\
\text { and abaca tidak dibuat-buat } \\
\text { atau sesuai dengan } \\
\text { kenyataannya }\end{array}$ & 2 & 8 & 25 & 41 & 20 & 357 & 3,72 \\
\hline \multicolumn{7}{|c|}{ Rata-rata } & & 3,75 \\
\hline
\end{tabular}

Sumber : Hasil penelitian, 2020

Berdasarkan tabel di atas dapat diketahui rata-rata jawaban responden untuk variabel Promosi $\left(\mathrm{X}_{1}\right)$ memiliki nilai rata-rata tertinggi yaitu $3.96 \%$ dan memiiki rata-rata terendah yaitu $3.51 \%$. Variabel Promosi menghasilkan nilai rata-rata sebesar $3.75 \%$. Menunjukan bahwa rata-rata pernyataan penilaian responden mengenai variabel Promosi adalah pada kategori baik. 


\subsubsection{Tanggapan Responden Terhadap Variabel Atribut Toko (Store Attributes)}

Hasil dari Distribusi frekuensi tanggapan responden terhadap variabel Atribut Toko $\left(\mathrm{X}_{2}\right)$ terhadap keputusan pembelian Ulang pada Nick Coffe di Kota Bengkulu, berdasarkan 27 pernyataan kuesioner kepada responden sebagai berikut

Tabel 4.9

Tanggapan Responden terhadap Atribut Toko ( $\left.\mathbf{X}_{2}\right)$

\begin{tabular}{|c|c|c|c|c|c|c|c|c|}
\hline No & Pernyataan Sikap Konsumen & STS & $\mathrm{TS}$ & $\mathrm{N}$ & $\mathrm{S}$ & SS & \multirow[t]{2}{*}{ Jumlah } & \multirow{2}{*}{$\begin{array}{r}\text { Rata- } \\
\text { rata }\end{array}$} \\
\hline & Lokasi & & & & & & & \\
\hline 1. & $\begin{array}{l}\text { Lokasi Nick Coffe mudah di } \\
\text { jangkau dengan transportasi } \\
\text { umum / pribadi }\end{array}$ & 2 & 7 & 21 & 38 & 28 & 371 & 3,86 \\
\hline 2. & $\begin{array}{l}\text { Lokasi Nick Coffe dekat } \\
\text { dengan fasilitas umum. }\end{array}$ & 4 & 13 & 18 & 38 & 23 & 351 & 3,66 \\
\hline \multirow[t]{2}{*}{3.} & $\begin{array}{l}\text { Lalu Lintas kendaraan di } \\
\text { sekitar Nick Coffe lancar }\end{array}$ & 1 & 9 & 18 & 45 & 23 & 368 & 3,83 \\
\hline & Harga & & & & & & & \\
\hline 4. & $\begin{array}{l}\text { Setiap produk yang } \\
\text { ditawarkan Nick Coffe } \\
\text { memiliki daftar harga yang } \\
\text { jelas. }\end{array}$ & 10 & 3 & 13 & 52 & 18 & 353 & 3,68 \\
\hline 5. & $\begin{array}{l}\text { Harga produk yang } \\
\text { ditawarkan Nick Coffe sesuai } \\
\text { dengan kualitas produk }\end{array}$ & 1 & 12 & 24 & 43 & 16 & 349 & 3,64 \\
\hline \multirow[t]{2}{*}{6.} & $\begin{array}{l}\text { Harga produk Nick Coffe } \\
\text { lebih murah dari harga yang } \\
\text { di tawarkan pesaing }\end{array}$ & 7 & 8 & 26 & 37 & 18 & 339 & 3,53 \\
\hline & Kualitas Barang & & & & & & & \\
\hline 7. & $\begin{array}{l}\text { Nick Coffe memiliki kualitas } \\
\text { produk sesuai harapan. }\end{array}$ & 1 & 9 & 29 & 40 & 17 & 351 & 3,66 \\
\hline
\end{tabular}




\begin{tabular}{|c|c|c|c|c|c|c|c|c|}
\hline 8. & $\begin{array}{l}\text { Produk yang ditawarkan oleh } \\
\text { Nick Coffe memiliki umur } \\
\text { ekonomis yang lama. }\end{array}$ & 3 & 6 & 26 & 39 & 22 & 359 & 3,74 \\
\hline \multirow[t]{2}{*}{9.} & $\begin{array}{l}\text { Produk yang ditawarkan Nick } \\
\text { Coffe layak untuk konsumsi }\end{array}$ & 2 & 2 & 26 & 48 & 18 & 366 & 3,81 \\
\hline & Keragaman Barang & & & & & & & \\
\hline 10. & $\begin{array}{l}\text { Nick Coffe menawarkan } \\
\text { ukuran produk yang } \\
\text { bervariasi. }\end{array}$ & 6 & 3 & 24 & 44 & 19 & 355 & 3,70 \\
\hline 11. & $\begin{array}{l}\text { Nick Coffe menawarkan } \\
\text { merek produk yang } \\
\text { bervariasi. }\end{array}$ & 6 & 6 & 22 & 40 & 22 & 354 & 3,69 \\
\hline \multirow[t]{2}{*}{12.} & $\begin{array}{l}\text { Nick Coffe menawarkan } \\
\text { kualitas produk yang } \\
\text { bervariasi. }\end{array}$ & 1 & 7 & 23 & 45 & 20 & 364 & 3,79 \\
\hline & Pelayanan & & & & & & & \\
\hline 13. & $\begin{array}{l}\text { Karyawan Nick Coffe } \\
\text { memberikan pelayanan } \\
\text { dengan ramah dan sopan. }\end{array}$ & 6 & 7 & 24 & 43 & 16 & 344 & 3,58 \\
\hline 14. & $\begin{array}{l}\text { Karyawan memberikan } \\
\text { pelayanan dengan cepat. }\end{array}$ & 4 & 4 & 25 & 48 & 15 & 354 & 3,69 \\
\hline \multirow[t]{2}{*}{15.} & $\begin{array}{l}\text { Konsumen tidak diawasi } \\
\text { secara langsung oleh } \\
\text { karyawan toko sehingga } \\
\text { membuat konsumen belanja } \\
\text { dengan santai. }\end{array}$ & 7 & 5 & 25 & 41 & 18 & 346 & 3,60 \\
\hline & Promosi & & & & & & & \\
\hline 16. & $\begin{array}{l}\text { Nick Coffe memberikan } \\
\text { diskon dalam periode tertentu } \\
\text { / tiap bulan. }\end{array}$ & 6 & 10 & 18 & 36 & 26 & 354 & 3,69 \\
\hline 17. & $\begin{array}{l}\text { Nick Coffe memeberikan } \\
\text { undian / kupon bagi } \\
\text { konsumen yang berbelanja } \\
\text { dalam nominal tertentu. }\end{array}$ & 1 & 6 & 24 & 38 & 27 & 372 & 3,88 \\
\hline 18. & $\begin{array}{l}\text { Nick Coffe memberikan } \\
\text { diskon spesial pada hari-hari } \\
\text { libur besar. }\end{array}$ & 5 & 11 & 22 & 45 & 13 & 338 & 3,52 \\
\hline
\end{tabular}




\begin{tabular}{|c|c|c|c|c|c|c|c|c|}
\hline & Fasilitas Fisik & & & & & & & \\
\hline 19. & $\begin{array}{l}\text { Nick Coffe memiliki lokasi } \\
\text { parkir yang aman. }\end{array}$ & 2 & 5 & 20 & 51 & 18 & 366 & 3,81 \\
\hline 20. & $\begin{array}{l}\text { Nick Coffe memiliki } \\
\text { penyejuk udara yang baik. }\end{array}$ & 8 & 2 & 18 & 53 & 15 & 353 & 3,68 \\
\hline 21. & $\begin{array}{l}\text { Keberadaan toko lain di } \\
\text { sekitar Nick Coffe sangat } \\
\text { mendukung. }\end{array}$ & 2 & 12 & 28 & 33 & 21 & 347 & 3,61 \\
\hline & Atmosfer & & & & & & & \\
\hline 22. & $\begin{array}{l}\text { Pajangan produk berada pada } \\
\text { ketinggian yang dapat } \\
\text { dijangkau oleh pandangan } \\
\text { mata. }\end{array}$ & 2 & 7 & 29 & 42 & 16 & 351 & 3,66 \\
\hline 23. & $\begin{array}{l}\text { Didalam ruangan toko } \\
\text { mengalun musik yang enak di } \\
\text { dengar. }\end{array}$ & 5 & 7 & 28 & 42 & 14 & 341 & 3,55 \\
\hline 24. & $\begin{array}{l}\text { Lorong lalu lintas kosumen } \\
\text { cukup luas }\end{array}$ & 3 & 4 & 23 & 42 & 24 & 368 & 3,83 \\
\hline & Pelayanan Purna Jual & & & & & & & \\
\hline 25 . & $\begin{array}{l}\text { Barang-barang Nick Coffe } \\
\text { yang tidak sesuai harapan } \\
\text { konsumen dapat } \\
\text { dikembalikan }\end{array}$ & 4 & 9 & 25 & 40 & 18 & 347 & 3,61 \\
\hline 26. & $\begin{array}{l}\text { Barang-barang Nick Coffe } \\
\text { yang tidak sesuai dengan } \\
\text { harapan konsumen dapat di } \\
\text { tukar dengan barang sejenis }\end{array}$ & 6 & 7 & 24 & 44 & 15 & 343 & 3,57 \\
\hline 27. & $\begin{array}{l}\text { Barang-barang Nick Coffe } \\
\text { memiliki garansi dari toko. }\end{array}$ & 7 & 10 & 18 & 36 & 25 & 350 & 3,65 \\
\hline \multicolumn{7}{|c|}{ Rata-rata } & & 3,68 \\
\hline
\end{tabular}

Sumber : Hasil penelitian, 2020

Berdasarkan tabel di atas dapat diketahui rata-rata jawaban responden untuk variabel Atribut Toko $\left(\mathrm{X}_{2}\right)$ memiliki nilai rata-rata tertinggi yaitu $3.88 \%$ dan memiliki rata-rata terendah yaitu $3.52 \%$. Variabel Atribut Toko menghasilkan 
nilai rata-rata sebesar $3.68 \%$. Menunjukan bahwa rata-rata pernyataan penilaian responden mengenai variabel Atribut Toko adalah pada kategori baik.

\subsubsection{Tanggapan Responden Terhadap Variabel Inovasi Produk}

Hasil dari Distribusi frekuensi tanggapan responden terhadap variabel Inovasi Produk $\left(\mathrm{X}_{3}\right)$ terhadap Keputusan Pembelian Ulang pada Nick Coffe Di Kota Bengkulu, berdasarkan 12 pernyataan kuesioner kepada responden sebagai berikut :

Tabel 4.10

Tanggapan Responden terhadap Inovasi Produk $\left(\mathbf{X}_{3}\right)$

\begin{tabular}{|c|c|c|c|c|c|c|c|c|}
\hline No & Pernyataan Sikap Konsumen & STS & $\mathrm{TS}$ & $\mathrm{N}$ & $\mathrm{S}$ & SS & \multirow[t]{2}{*}{ Jumlah } & \multirow{2}{*}{$\begin{array}{l}\text { Rata- } \\
\text { rata }\end{array}$} \\
\hline & Produk Baru Bagi Dunia & & & & & & & \\
\hline 1 & $\begin{array}{l}\text { Menu unik pada Nick Coffe } \\
\text { merupakan produk yang belm } \\
\text { pernah dibuat oleh café lainnya }\end{array}$ & 0 & 4 & 25 & 40 & 27 & 378 & 3,94 \\
\hline 2. & $\begin{array}{l}\text { Menu unik Nick Coffe } \\
\text { mempunyai ciri khas yang } \\
\text { berbeda dengan produk café } \\
\text { lainnya }\end{array}$ & 2 & 11 & 20 & 40 & 23 & 359 & 3,74 \\
\hline & Lini Produk Baru & & & & & & & \\
\hline 3. & $\begin{array}{l}\text { Nick Coffe memungkinkan } \\
\text { untuk masuk dalam persaingan } \\
\text { pasar yang telah ada }\end{array}$ & 1 & 3 & 18 & 45 & 29 & 386 & 4,02 \\
\hline 4. & $\begin{array}{l}\text { Nick Coffe memberikan } \\
\text { pilihan pada konsumen untuk } \\
\text { menentukan pilihan café yang } \\
\text { akan dikunjungi }\end{array}$ & 7 & 1 & 15 & 57 & 16 & 362 & 3,77 \\
\hline & $\begin{array}{l}\text { Tambahan Pada Lini Produk } \\
\text { yang Telah Ada }\end{array}$ & & & & & & & \\
\hline 5. & $\begin{array}{l}\text { Nick Coffe semakin } \\
\text { melengkapi café-café yang } \\
\text { telah ada di Bengkulu }\end{array}$ & 3 & 9 & 27 & 40 & 17 & 347 & 3,61 \\
\hline
\end{tabular}




\begin{tabular}{|c|c|c|c|c|c|c|c|c|}
\hline 6. & $\begin{array}{l}\text { Nick Coffe menjadikan pilihan } \\
\text { menu unik yang beragam } \\
\text { sehingga memunculkan banyak } \\
\text { pilihan }\end{array}$ & 3 & 5 & 27 & 39 & 22 & 360 & 3,75 \\
\hline & $\begin{array}{l}\text { Perbaikan \& Revisi Produk } \\
\text { yang Telah Ada }\end{array}$ & & & & & & & \\
\hline 7. & $\begin{array}{l}\text { Perbaikan selalu dilakukan } \\
\text { Nick Coffe untuk } \\
\text { meningkatkan kualitasnya }\end{array}$ & 1 & 9 & 26 & 39 & 21 & 358 & 3,73 \\
\hline 8. & $\begin{array}{l}\text { Perbaikan yang dilakukan Nick } \\
\text { Coffe dapat memberikan nilai } \\
\text { yang lebih dibandingkan } \\
\text { produk-produk sebelumnya }\end{array}$ & 3 & 5 & 25 & 38 & 25 & 365 & 3,80 \\
\hline & Penentuan Kembali & & & & & & & \\
\hline 9. & $\begin{array}{l}\text { Nick Coffe berupaya untuk } \\
\text { megembangkan pasar baru } \\
\text { dalam dunia kuliner }\end{array}$ & 2 & 2 & 24 & 47 & 21 & 371 & 3,86 \\
\hline 10. & $\begin{array}{l}\text { Pengembangan Nick Coffe } \\
\text { dapat meningkatkan volume } \\
\text { penjualan }\end{array}$ & 3 & 5 & 24 & 44 & 20 & 361 & 3,76 \\
\hline & Pengurangan Biaya & & & & & & & \\
\hline 11. & $\begin{array}{l}\text { Nick Coffe berupaya menekan } \\
\text { biaya untuk menghasilkan } \\
\text { produk yang mempunyai daya } \\
\text { saing harga }\end{array}$ & 4 & 4 & 21 & 41 & 26 & 369 & 3,84 \\
\hline 12. & $\begin{array}{l}\text { Nick Coffe membuat menu } \\
\text { unik dengan harga murah } \\
\text { dengan kualitas yang baik }\end{array}$ & 0 & 7 & 22 & 47 & 20 & 368 & 3,83 \\
\hline \multicolumn{7}{|c|}{ Rata-rata } & & 3,80 \\
\hline
\end{tabular}

Sumber : Hasil penelitian, 2020

Berdasarkan tabel di atas dapat diketahui rata-rata jawaban responden untuk variabel Inovasi Produk $\left(\mathrm{X}_{3}\right)$ memiliki nilai rata-rata tertinggi yaitu $4.02 \%$ dan memiliki rata-rata terendah yaitu 3.61\%. Variabel Inovasi Produk menghasilkan 
nilai rata-rata sebesar $3.80 \%$. Menunjukan bahwa rata-rata pernyataan penilaian responden mengenai variabel Kualitas Produk adalah pada kategori baik.

\subsubsection{Tanggapan Responden Terhadap Variabel Keputusan Pembelian Ulang}

Hasil dari Distribusi frekuensi tanggapan responden terhadap variabel Keputusan Pembelian Ulang (Y) pada Nick Coffe di Kota Bengkulu, berdasarkan 10 pernyataan kuesioner kepada responden sebagai berikut

Tabel 4.11

Tanggapan Responden terhadap Keputusan Pembelian Ulang (Y)

\begin{tabular}{|c|c|c|c|c|c|c|c|c|}
\hline No & Pernyataan Sikap Konsumen & STS & $\mathrm{TS}$ & $\mathrm{N}$ & $\mathrm{S}$ & SS & \multirow[t]{2}{*}{ Jumlah } & \multirow{2}{*}{$\begin{array}{l}\text { Rata- } \\
\text { rata }\end{array}$} \\
\hline & Pengenalan Kebutuhan & & & & & & & \\
\hline 1 . & $\begin{array}{l}\text { Saya memutuskan membeli } \\
\text { produk pada Nick Coffe karena } \\
\text { sesuai kebutuhan }\end{array}$ & 3 & 3 & 21 & 46 & 23 & 371 & 3,86 \\
\hline \multirow[t]{2}{*}{2.} & $\begin{array}{l}\text { Berbagai produk minuman } \\
\text { yang saya butuhkan tersedia di } \\
\text { Nick Coffe }\end{array}$ & 0 & 7 & 26 & 41 & 22 & 366 & 3,81 \\
\hline & Pencarian Informasi & & & & & & & \\
\hline 3. & $\begin{array}{l}\text { Nick Coffe memberikan } \\
\text { informasi mengenai produk } \\
\text { yang ditawarkan }\end{array}$ & 4 & 4 & 26 & 39 & 23 & 361 & 3,76 \\
\hline \multirow[t]{2}{*}{4.} & $\begin{array}{l}\text { Informasi yang diberikan di } \\
\text { Nick Coffe sangat membantu } \\
\text { dalam memilih produk }\end{array}$ & 1 & 2 & 24 & 50 & 19 & 372 & 3,88 \\
\hline & Evaluasi Alternatif & & & & & & & \\
\hline 5. & $\begin{array}{l}\text { Saya membeli minuman di } \\
\text { Nick Coffe }\end{array}$ & 7 & 4 & 24 & 39 & 22 & 353 & 3,68 \\
\hline 6. & $\begin{array}{l}\text { Saya merasa puas setelah } \\
\text { membeli produk minuman di } \\
\text { Nick Coffe }\end{array}$ & 4 & 2 & 22 & 41 & 27 & 373 & 3,89 \\
\hline & Keputusan Pembelian & & & & & & & \\
\hline
\end{tabular}




\begin{tabular}{|c|c|c|c|c|c|c|c|c|}
\hline 7. & $\begin{array}{l}\text { Nick Coffe banyak mempunyai } \\
\text { kelebihan dibandingkan toko } \\
\text { lain }\end{array}$ & 0 & 3 & 22 & 44 & 27 & 383 & 3,99 \\
\hline \multirow[t]{2}{*}{8.} & $\begin{array}{l}\text { Produk yang dijual di Nick } \\
\text { Coffe lebih lengkap dibanding } \\
\text { toko lain }\end{array}$ & 2 & 10 & 18 & 48 & 18 & 358 & 3,73 \\
\hline & Prilaku Setelah Pembelian & & & & & & & \\
\hline 9. & $\begin{array}{l}\text { Saya akan mengatakan } \\
\text { keunggulan Nick Coffe kepada } \\
\text { orang lain }\end{array}$ & 2 & 4 & 18 & 47 & 25 & 377 & 3,93 \\
\hline 10. & $\begin{array}{l}\text { Saya akan berbelanja di Nick } \\
\text { Coffe lagi jika membutuhkan } \\
\text { minuman }\end{array}$ & 7 & 2 & 17 & 55 & 15 & 357 & 3,72 \\
\hline \multicolumn{7}{|c|}{ Rata-rata } & & 3,82 \\
\hline
\end{tabular}

Sumber : Hasil penelitian, 2020

Berdasarkan tabel diatas dapat diketahui rata-rata jawaban responden untuk variabel Keputusan Pembelian Ulang (Y) memiliki nilai rata-rata tertinggi yaitu 3,99\% dan memiliki rata-rata terendah yaitu 3,68\%. Variabel Keputusan Pembelian Ulang menghasilkan nilai rata-rata sebesar 3,82\%. Menunjukan bahwa rata-rata pernyataan penilaian responden mengenai variabel Keputusan Pembelian Ulang adalah pada kategori baik.

Nilai ini menunjukkan tanggapan responden atas variabel Keputusan Pembelian Ulang (Y) berada pada kriteria setuju. Jadi dalam pengambilan Keputusan Pembelian Ulang memilih berbelanja dengan obyektif, rasional dan terencana sehingga konsumen dapat memilih berbelanja di Nick Coffe di Kota Bengkulu. 


\subsubsection{Uji Asumsi Klasik}

\subsubsection{Uji Normalitas}

Tabel 4.12

Uji Normalitas

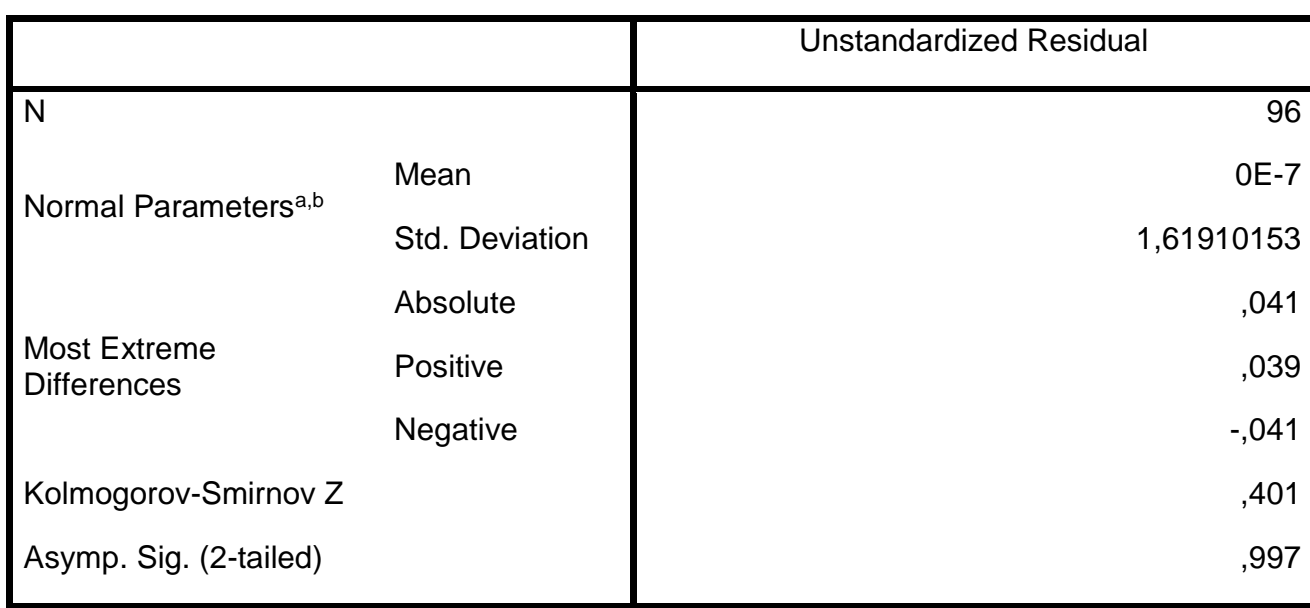

Sumber: Output SPSS 23 yang diolah, 2020

Berdasarkan tabel output SPSS tersebut, diketahui bahwa nilai signifikasi Asymp. Sig. (2-tailed) sebesar 0.997 lebih besar dari 0.05. Maka sesuai dengan dasar pengambilan keputusan dalam uji normalitas Kolmogorov-smirnov diatas dapat disimpulkan bahwa data berdistribusi normal.

\subsubsection{Uji Multikolinearitas}

Uji multikolinearitas ini bertujuan untuk mengetahui apakah tiap-tiap variabel bebas yaitu faktor Kualitas Produk dan Pelayanansaling berhubungan secara linear. Pengujian adanya multikolinearitas ini dapat dilakukan dengan melihat nilai toleransi diatas 0,1 dan VIF nya lebih kecil dari 10 tidak ada kecenderungan terjadi gejala multikolinear. 
Tabel 4.13

Hasil Uji Multikolinearitas

\begin{tabular}{|c|c|c|c|c|}
\hline No & Variabel & Tolerance & VIF & Keterangan \\
\hline 1 & Promosi & 0,376 & 2,658 & Non Multikolinearitas \\
\hline 2 & Atribut Toko & 0,518 & 1,931 & Non Multikolinearitas \\
\hline 3 & Inovasi Produk & 0,415 & 2,408 & Non Multikolinearitas \\
\hline
\end{tabular}

Sumber: Output SPSS 23 yang diolah, 2020

Sesuai dengan ketentuan uji Multikolinieritas, Sehingga dapat disimpulkan bahwa tidak terdapat multikolinieritas dalam data penelitian ini. Artinya bahwa antara variabel Promosi (X1), Atribut Toko (X2), dan Inovasi Produk (X3) tidak saling mengganggu atau mempengaruhi.

\subsubsection{Uji Heteroskedastisitas}

Uji heterokedasitas bertujuan untuk menguji apakah dalam model regresi terjadi ketidak sama varians.

\section{Gambar 4.1}

\section{Hasil Uji Heteroskedastisitas}

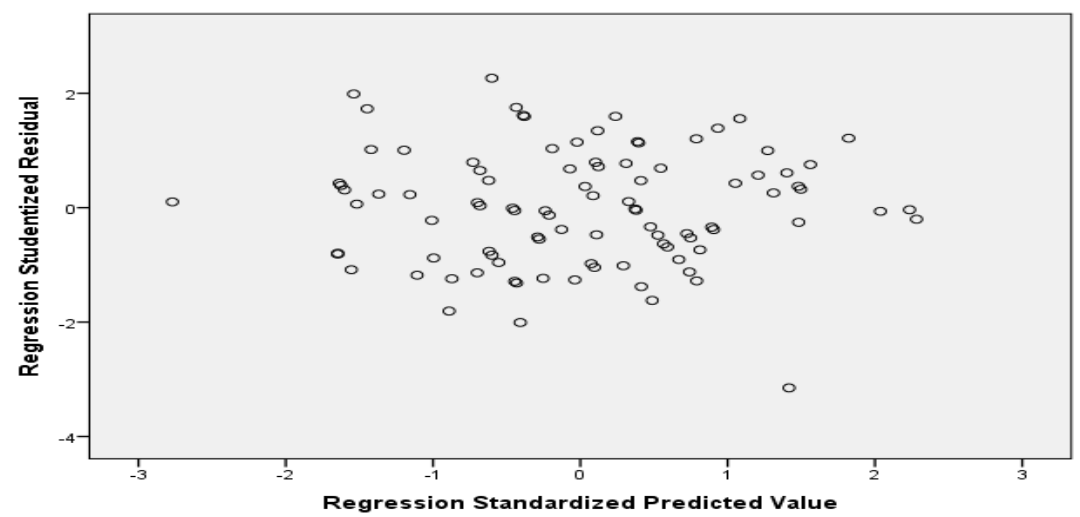

Sumber : Output SPSS 23 yang diolah, 2020 
Dasar Analisa Uji Heteroskodesitas dengan grafik plot adalah jika titik dalam grafik tersebar (tidak membentuk pola) maka tidak terjadi Heteroskodesitas. Berdasarkan gambar tersebut dapat dilihat bahwa titik-titik yang ada tidak membentuk pola yang teratur. Sehingga dapat disimpulkan bahwa pada data dalam penelitian ini tidak terjadi Heteroskodesitas. Artinya dalam fungsi regresi di penelitian ini tidak muncul gangguan karena varian yang tidak sama.

\subsection{Analisis Persamaan Regresi Linier Berganda}

Analisis persamaan regresi linier berganda digunakan dalam penelitian ini dengan tujuan untuk mengetahui ada tidaknya pengaruh variabel bebas terhadap variabel terikat. Perhitungan statistik dalam analisis regresi linear berganda yang digunakan dalam penelitian ini adalah dengan menggunakan bantuan program komputer SPSS for Windows versi 23. Ringkasan hasil pengolahan data dengan menggunakan program SPSS tersebut terdapat pada tabel berikut ini :

Tabel 4.14

Regresi Linier Berganda

\begin{tabular}{|c|c|c|c|c|c|}
\hline \multirow[t]{2}{*}{ Model } & \multicolumn{2}{|c|}{ Unstandardized Coefficients } & \multirow{2}{*}{$\begin{array}{c}\begin{array}{c}\text { Standardized } \\
\text { Coefficients }\end{array} \\
\text { Beta }\end{array}$} & \multirow[t]{2}{*}{$\mathrm{t}$} & \multirow[t]{2}{*}{ Sig. } \\
\hline & B & Std. Error & & & \\
\hline (Constant) & 2,063 & 1,399 & & 1,474 & 144, \\
\hline Promosi & , 192 & ,052 & ,200 & 3,708 &, 000 \\
\hline Atribut Tokoh & 036 & 017 & 097 & 2,113 & ,037 \\
\hline Inovasi Produk &, 713 & 043 & 852 & 16,592 &, 000 \\
\hline
\end{tabular}

Sumber : Hasil penelitian, 2020 
Dari perhitungan menggunakan SPSS versi 23 for windows didapatkan persamaan regresinya adalah :

$Y=2.063+0.192 X_{1}+0.036 X_{2}+0.713 X_{3}$

Angka tersebut masing-masing secara ekonomis dapat dijelaskan sebagai berikut :

1. Nilai Konstanta 2.063 mempunyai arti bahwa apabila variabel Promosi $\left(\mathrm{X}_{1}\right)$, Atribut Toko $\left(\mathrm{X}_{2}\right)$, Inovasi Produk $\left(\mathrm{X}_{3}\right)$, terhadap keputusan pembelian Ulang (Y), sama dengan nol maka variabel keputusan pembelian akan tetap yaitu 2.063. Hasil ini berlaku saat dilaksanakannya penelitian.

2. Koefisien regresi variabel Promosi $\left(\mathrm{X}_{1}\right)$ sebesar 0.192 mempunyai makna bahwa apabila Promosi $\left(\mathrm{X}_{1}\right)$ ditingkatkan satu satuan, maka akan meningkatkan keputusan pembelian Ulang (Y) pada Masyarakat Kota Bengkulu sebesar 0.192 dengan asumsi variabel Atribut Toko $\left(\mathrm{X}_{2}\right)$, dan Inovasi Produk $\left(\mathrm{X}_{3}\right)$ dianggap tetap.

3. Koefisien regresi variabel Atribut Toko $\left(\mathrm{X}_{2}\right)$ sebesar 0.036 mempunyai makna bahwa apabila Atribut Toko $\left(\mathrm{X}_{2}\right)$ ditingkatkan satu satuan, maka akan meningkatkan keputusan pembelian Ulang (Y) pada Masyarakat Kota Bengkulu sebesar 0.036 dengan asumsi variabel Promosi $\left(\mathrm{X}_{1}\right)$, dan Inovasi Produk $\left(\mathrm{X}_{3}\right)$ dianggap tetap.

4. Koefisien regresi variabel Inovasi Produk $\left(\mathrm{X}_{3}\right)$ sebesar 0.713 mempunyai makna bahwa apabila Inovasi Produk $\left(\mathrm{X}_{3}\right)$ ditingkatkan satu satuan, maka akan meningkatkan keputusan pembelian Ulang (Y) 
pada Masyarakat Kota Bengkulu sebesar 0.713 dengan asumsi variabel Promosi $\left(\mathrm{X}_{1}\right)$, dan Atribut Toko $\left(\mathrm{X}_{2}\right)$ dianggap tetap .

5. Hasil penelitian dalam penelitian yang paling dominan mempengaruhi variable Keputusan Pembelian (Y) adalah Variabel Promosi $\left(\mathrm{X}_{1}\right)$ adalah sebesar 0.92, Atribut Toko $\left(\mathrm{X}_{2}\right)$ adalah sebesar 0.036, dan Inovasi Produk $\left(\mathrm{X}_{3}\right)$ adalah sebesar 0.713

\subsection{Analisis Koefisien Determinasi $\left(\mathbf{R}^{2}\right)$}

Koefisien determinasi digunakan untuk mengetahui presentase sumbangan pengaruh variabel bebas Promosi $\left(\mathrm{X}_{1}\right)$, Atribut Toko $\left(\mathrm{X}_{2}\right)$, dan Inovasi Produk $\left(\mathrm{X}_{3}\right)$ terhadap Keputusan Pembelian Ulang $(\mathrm{Y})$ maka dari perhitungan computer menggunakan SPSS versi 23 for windows. Adapun rekapitulasi hasil pengujian koefisien determinasi dapat dilihat pada tabel berikut ini :

Tabel 4.15

Nilai Koefisien Determinasi Hasil Penelitian

\begin{tabular}{|l|r|r|r|r|}
\hline Model & \multicolumn{1}{|c|}{$\mathrm{R}$} & R Square & Adjusted R Square & \multicolumn{1}{|c|}{ Std. Error of the Estimate } \\
\hline 1 &, $948^{\mathrm{a}}$ &, 899 &, 896 & 1,644 \\
\hline
\end{tabular}

Sumber : Hasil penelitian, 2020

Berdasarkan tabel di atas dapat diketahui bahwa nilai Adjusted $R$ square yang digunakan untuk mengukur seberapa jauh kemampuan model dalam menerangkan variasi variabel dependen 0.899 . Hal ini menunjukan bahwa sebesar 89.9\% keputusan pembelian Ulang pada Nick Coffe di Kota Bengkulu 
dipengaruhi oleh variasi dari ketiga variabel independen, yaitu Promosi $\left(\mathrm{X}_{1}\right)$, Atribut Toko $\left(\mathrm{X}_{2}\right)$, Inovasi Produk $\left(\mathrm{X}_{3}\right)$, terhadap keputusan pembelian Ulang $(\mathrm{Y})$, sedangkan sisanya $(100-89.9 \%=10.1 \%)$ dijelaskan oleh variabel - variabel diluar variabel penelitian ini.

\subsection{Uji Hipotesis}

Uji hipotesis bertujuan untuk mengetahui apakah ada tidaknya pengaruh yang signifikan antara variabel independen (Promosi, Atribut Toko (Store Attributes), dan Inovasi Produk) terhadap variabel dependen (keputusan Pembelian Ulang) baik secara parsial maupun simultan.

\subsubsection{Uji $-\mathbf{t}$}

Untuk menguji pengaruh variabel bebas secara parsial terhadap variabel terikat digunakan uji t sebagai berikut :

Tabel 4.16

\section{Uji T (Uji Secara Parsial)}

\begin{tabular}{|c|c|c|c|c|c|}
\hline \multirow[t]{2}{*}{ Model } & \multicolumn{2}{|c|}{ Unstandardized Coefficients } & \multirow{2}{*}{$\begin{array}{c}\begin{array}{c}\text { Standardized } \\
\text { Coefficients }\end{array} \\
\text { Beta }\end{array}$} & \multirow[t]{2}{*}{$\mathrm{t}$} & \multirow[t]{2}{*}{ Sig. } \\
\hline & B & Std. Error & & & \\
\hline (Constant) & 2,063 & 1,399 & & 1,474 & , 144 \\
\hline Promosi & , 192 & 052 & ,200 & 3,708 &, 000 \\
\hline Atribut Tokoh & 036 & 017 & 097 & 2,113 & 037 \\
\hline Inovasi Produk & ,713 & ,043 & ,852 & 16,592 &, 000 \\
\hline
\end{tabular}

Sumber : Hasil penelitian, 2020

Dari hasil perhitungan di atas maka dapat dijelaskan bahwa Promosi $\left(\mathrm{X}_{1}\right)$ menunjukkan nilai signifikansi sebesar $0.000<0.05$, karena nilai signifikansi 
lebih kecil dari 0.05, maka H0 ditolak dan Ha diterima. Artinya Promosi $\left(\mathrm{X}_{1}\right)$ memiliki pengaruh yang positif dan signifikan terhadap Keputusan Pembelian Ulang (Y).

Hasil pengujian untuk variabel Atribut Toko $\left(\mathrm{X}_{2}\right)$ menunjukkan nilai signifikansi sebesar $0.037<0.05$. Karena nilai signifikansi lebih kecil dari 0.05 maka H0 ditolak dan Ha diterima. Artinya Atribut Toko $\left(\mathrm{X}_{2}\right)$ memiliki pengaruh yang positif dan signifikan terhadap Keputusan Pembelian Ulang (Y).

Hasil pengujian untuk variabel Inovasi Produk $\left(\mathrm{X}_{3}\right)$ menunjukkan nilai signifikansi sebesar $0.000<0.05$. Karena nilai signifikansi lebih kecil dari 0.05 , maka $\mathrm{H} 0$ ditolak dan $\mathrm{Ha}$ diterima. Artinya Inovasi Produk $\left(\mathrm{X}_{3}\right)$ memiliki pengaruh yang positif dan signifikan terhadap Keputusan Pembelian Ulang (Y).

\subsubsection{Uji F}

Dalam penelitian ini pengujian hipotesis dimaksudkan untuk mengukur besarnya pengaruh Promosi $\left(\mathrm{X}_{1}\right)$, Atribut Toko $\left(\mathrm{X}_{2}\right)$, dan Inovasi $\operatorname{Produk}\left(\mathrm{X}_{3}\right)$ berpengaruh terhadap Keputusan Pembelian Ulang (Y) maka digunakan uji F. Berdasarkan hasil pengujian hipotesis Uji Anova atau uji $\mathrm{F}$ terlihat pada tabel berikut:

Tabel 4.17

Uji F (Uji secara simultan)

\begin{tabular}{|c|c|c|c|c|c|c|}
\hline \multicolumn{2}{|c|}{ Model } & Sum of Squares & df & Mean Square & $\mathrm{F}$ & Sig. \\
\hline \multirow{3}{*}{1} & Regression & 2222,764 & 3 & 740,921 & 274,056 &, $000^{\mathrm{b}}$ \\
\hline & Residual & 248,726 & 92 & 2,704 & & \\
\hline & Total & 2471,490 & 95 & & & \\
\hline
\end{tabular}

Sumber : Hasil penelitian, 2020 
Hasil perhitungan statistik menunjukkan nilai signifikansi sebesar 0.000 <0.05. Karena nilai signifikansi di bawah 0.05 menunjukkan bahwa secara bersama-sama Promosi $\left(\mathrm{X}_{1}\right)$, Atribut Toko $\left(\mathrm{X}_{2}\right)$, dan Inovasi Produk $\left(\mathrm{X}_{3}\right)$ mempunyai pengaruh yang positif dan signifikan terhadap Keputusan Pembelian Ulang (Y). Maka berdasarkan hasil uji simultan maka H0 ditolak dan $\mathrm{Ha}$ diterima, antara Variabel-variabel bebas yaitu Promosi $\left(\mathrm{X}_{1}\right)$, Atribut Toko $\left(\mathrm{X}_{2}\right)$, dan Inovasi Produk $\left(\mathrm{X}_{3}\right)$ mempunyai pengaruh yang signifikan secara bersamasama terhadap Keputusan Pembelian Ulang (Y)

\subsection{Pembahasan Hasil Penelitian}

Berdasarkan hasil penelitian dan pengolahan data mentah yang di lakukan pada Konsumen Nick coffe di Kota Bengkulu, melalui penyebaran kuesioner terhadap 96 orang responden yang telah diuji sehingga dapat diketahui pengaruh Promosi, Atribut Toko (Store Attributes), dan Inovasi Produk terhadap Keputusan Pembelian Ulang pada Nick Coffe di Kota Bengkulu :

\subsubsection{Promosi pada Nick Coffe di Kota Bengkulu}

Hasil penelitiaan ini menyatakan bahwa Promosi sudah dikatakan baik. hal ini dapat lihat pada Nick Coffe di Kota Bengkulu yang sering melakukan Promosi melalui Media sosial, memberikan diskon pada saat - saat tertentu, dan terkadang memberikan kuis ini semua dilakukan untuk menarik konsumen melakukan Keputusan Pembelian dan kembali lagi melakukan keputusan pembelian ulang. Nick Coffe di Kota bengkulu sudah mulai meningkat di bandingkan dengan sebelumya. Kemudiaan dapat di lihat dari tanggapan responden, variabel Promosi 
$\left(\mathrm{X}_{1}\right)$ berada pada kategori baik dengan nilai tertinggi 3.96 dan memilki terendah 3.51, maksudnya adalah Promosi pada Nick Coffe di Kota Bengkulu sudah baik. Dilihat dari promosi yang di lakukan Nick Coffe Kepada Para Konsumen.

\subsubsection{Atribut Toko (Store Attributes) pada Nick Coffe di Kota Bengkulu}

Hasil penelitiaan ini menyatakan bahwa Atribut Toko sudah dikatakan baik. hal ini dapat lihat pada Nick Coffe di Kota Bengkulu yang memberikan Harga yang lebih murah, serta kualitas yang baik, mempunyai lokasi yang mudah di jangkau, tempat Parkir yang luas untuk kendraan roda dua, dan empat, seta toko yang selalu mengikuti zaman atau biasa di sebut instagramable. Jumlah Konsumen Nick Coffe di Kota Bengkulu sudah mulai meningkat di bandingkan dengan sebelumya. Kemudiaan dapat di lihat dari tanggapan responden, variabel Atribut Toko $\left(\mathrm{X}_{2}\right)$ berada pada kategori baik dengan nilai tertinggi 3.88 dan memilki terendah 3.52, maksudnya adalah Atribut Toko pada Nick Coffe di Kota Bengkulu sudah baik.

\subsubsection{Inovasi Produk pada Nick Coffe di Kota Bengkulu}

Hasil penelitiaan ini menyatakan bahwa Inovasi Produk sudah dikatakan baik. hal ini dapat lihat pada Nick Coffe di Kota Bengkulu yang sering melakukan Pembaharuan produk yang mereka jual, selalu mengikuti trend di masa kini, dan selalu berinovasi memberikan ciri khas yang berbeda dari toko yang lain. Nick Coffe di Kota bengkulu sudah mulai meningkat di bandingkan dengan sebelumya. Kemudiaan dapat di lihat dari tanggapan responden, variabel Inovasi Produk $\left(\mathrm{X}_{3}\right)$ berada pada kategori baik dengan nilai tertinggi 4.02 dan memilki terendah 3.61, 
maksudnya adalah Inovasi Produk pada Nick Coffe di Kota Bengkulu sudah baik. Dilihat dari Selalu Meningkatnya jumlah Pengunjung Untuk Mencoba Produk terbaru di Nick Coffe.

\subsubsection{Keputusan Pembelian Ulang pada Nick Coffe di Kota Bengkulu}

Hasil penelitiaan ini menyatakan bahwa Keputusan Pembelian Ulang sudah dikatakan baik. hal ini dapat lihat pada Nick Coffe di Kota Bengkulu yang selalu memiliki pelanggan setia, dan juga pelanggan yang baru untuk mencicipi menu terbaru, menu yang menjadi favorite konsumennya. Nick Coffe di Kota bengkulu sudah mulai meningkat di bandingkan dengan sebelumya. Kemudiaan dapat di lihat dari tanggapan responden, variabel Keputusan Pembelian Ulang (Y) berada pada kategori baik dengan nilai tertinggi 3.99 dan memilki terendah 3.68, maksudnya adalah Keputusan Pembelian Ulang pada Nick Coffe di Kota Bengkulu sudah baik. Dilihat dari Selalu Meningkatnya jumlah Pengunjung, dan banyaknya konsumen yang melakukan pembelian ulang.

\subsubsection{Pengaruh Promosi $\left(\mathrm{X}_{1}\right)$ Terhadap Keputusan Pembelian Ulang (Y)}

Berdasarkan hasil penelitian dan pengolahan data yang dilakukan Pada Nick Coffe di Kota Bengkulu melalui penyebaran kuesioner terhadap 96 orang responden yang telah diuji sehingga dapat diketahui pengaruh Promosi terhadap Keputusan Pembelian Ulang pada Nick Coffe di Kota Bengkulu.

Dari analisis regresi linear berganda diperoleh persamaan $\mathrm{Y}=1.688+$ $0.192\left(\mathrm{X}_{1}\right)$ angka ini mempunyai makna nilai konstanta 1.688 mempunyai arti bahwa variable Promosi $\left(\mathrm{X}_{1}\right)$ terhadap Keputusan Pembelian Ulang (Y) pada Nick 
Coffe di Kota Bengkulu sama dengan nol, maka variable Keputusan Pembelian Ulang akan tetap yaitu, 1.688. hal ini berlaku saat dilaksanakan penelitiaan. Koefisien regresi variable Promosi $\left(\mathrm{X}_{1}\right)$ sebesar 0.192 dan mempunyai makna bahwa apabila Promosi $\left(\mathrm{X}_{1}\right)$ ditingkatkan, maka akan meningkatan Keputusan Pembelian Ulang (Y) pada Nick Coffe di Kota Bengkulu.

Promosi memiliki pengaruh terhadap Keputusan Pembelian Ulang. Hal ini terlihat pada uji t yang menyatakan memiliki nilai $t_{h i t}>t_{\alpha / 2}(3.708>1.985)$ dan ( $\operatorname{sig} \alpha=0.000<0.050$ ), maka dari penelitian yang dilakukan dalam penelitian terdahulu menyatakan bahwa Promosi memiliki pengaruh positif dan berpengaruh signifikan terhadap Keputusan Pembelian Ulang.

Hasil penelitian ini sejalan dengan penelitan yang dilakukan oleh Dwi Yuli Astuti (2018) dengan judul "Pengaruh harga promosi terhadap minat pembelian ulang Pada evaluasi pembeli starbucks coffee di yogyakarta" hasil penelitian menunjukkan bahwa ada pengaruh positif dan signifikan harga promosi terhadap minat pembelian ulang.

Hasil penelitian ini sejalan dengan penelitan yang dilakukan oleh Intan Mawarsari (2018) dengan judul "Pengaruh kualitas produk, harga, dan promosi terhadap minat beli ulang konsumen olahan buah carica di daerah" Hasil dari penelitian ini bahwa harga, dan promosi berpengaruh positif terhadap minat beli ulang.

Hasil penelitian ini sejalan dengan penelitan yang dilakukan oleh Younes Ben Said, Nicola Luigi Bragazzi, and Natalia Valeryevna Pyatigorskaya(2019) dengan judul “Influence of Sales Promotion Techniques on Consumers' 
Purchasing Decisions at Community Pharmacies" menyatakan bahwa The research findings identified that, according to all respondents, the following sales promotion tools had the strongest impact on consumers' purchasing decisions.

\subsubsection{Pengaruh Atribut Toko $\left(X_{2}\right)$ Terhadap Keputusan Pembelian Ulang}

$(\mathbf{Y})$

Berdasarkan hasil penelitian dan pengolahan data yang dilakukan Pada Nick Coffe di Kota Bengkulu melalui penyebaran kuesioner terhadap 96 orang responden yang telah diuji sehingga dapat diketahui pengaruh Atribut Toko terhadap Keputusan Pembelian Ulang pada Nick Coffe di Kota Bengkulu.

Dari analisis regresi linear berganda diperoleh persamaan $\mathrm{Y}=1.688+$ $0.036\left(\mathrm{X}_{2}\right)$ angka ini mempunyai makna nilai konstanta 1.688 mempunyai arti bahwa variable Atribut Toko $\left(\mathrm{X}_{2}\right)$ terhadap Keputusan Pembelian Ulang (Y) pada Nick Coffe di Kota Bengkulu sama dengan nol, maka variable Keputusan Pembelian Ulang akan tetap yaitu, 1.688. hal ini berlaku saat dilaksanakan penelitiaan. Koefisien regresi variable Atribut Toko $\left(\mathrm{X}_{2}\right)$ sebesar 0.036 dan mempunyai makna bahwa apabila Atribut Toko $\left(\mathrm{X}_{2}\right)$ ditingkatkan, maka akan meningkatan Keputusan Pembelian Ulang (Y) pada Nick Coffe di Kota Bengkulu.

Atribut Toko memiliki pengaruh terhadap Keputusan Pembelian Ulang. Hal ini terlihat pada uji $\mathrm{t}$ yang menyatakan memiliki nilai $t_{h i t}>t_{\alpha / 2}(2.113>$ 1.985) dan ( $\operatorname{sig} \alpha=0.037<0.050)$, maka dari penelitian yang dilakukan dalam penelitian terdahulu menyatakan bahwa Atribut Toko memiliki pengaruh positif dan berpengaruh signifikan terhadap Keputusan Pembelian Ulang.

Hasil penelitian ini sejalan dengan penelitan yang dilakukan oleh 
Muhyidin (2017) dengan judul "Pengaruh atribut toko terhadap keputusan pembelian barang di toko ritel (studi khasus pada toko basmalah pada cabang rembang kabupaten pasuruan jawa timur)". Hasil dri penelitian ini bahwasannya atribut toko sangat berpengaruh (positif) terhadap keputusan pembelian.

Hasil penelitian ini sejalan dengan penelitan yang dilakukan oleh Ms. D.Alamemu (2018) dengan judul "A Study on the Attributes Influencing the Purchasing Behaviour of Apparel Consumer in Organized Retail with Special Reference to Max Retail Division" Hasil dari penelitian ini However all the five attributes quality, price, appeal, brand and variety influence each other in which variety and brandhas a moderate positive correlation while purchasing a product from the outlet.

\subsubsection{Pengaruh Inovasi Produk $\left(X_{3}\right)$ Terhadap Keputusan Pembelian Ulang}

$(\mathbf{Y})$

Berdasarkan hasil penelitian dan pengolahan data yang dilakukan Pada Nick Coffe di Kota Bengkulu melalui penyebaran kuesioner terhadap 96 orang responden yang telah diuji sehingga dapat diketahui pengaruh Inovasi Produk terhadap Keputusan Pembelian Ulang pada Nick Coffe di Kota Bengkulu.

Dari analisis regresi linear berganda diperoleh persamaan $\mathrm{Y}=1.688+$ $0.713\left(\mathrm{X}_{3}\right)$ angka ini mempunyai makna nilai konstanta 1.688 mempunyai arti bahwa variable Inovasi Produk $\left(\mathrm{X}_{3}\right)$ terhadap Keputusan Pembelian Ulang (Y) pada Nick Coffe di Kota Bengkulu sama dengan nol, maka variable Keputusan Pembelian Ulang akan tetap yaitu, 1.688. hal ini berlaku saat dilaksanakan penelitiaan. Koefisien regresi variable Inovasi Produk $\left(\mathrm{X}_{3}\right)$ sebesar 0.713 dan 
mempunyai makna bahwa apabila Inovasi Produk $\left(\mathrm{X}_{3}\right)$ ditingkatkan, maka akan meningkatan Keputusan Pembelian Ulang (Y) pada Nick Coffe di Kota Bengkulu.

Inovasi Produk memiliki pengaruh terhadap Keputusan Pembelian Ulang. Hal ini terlihat pada uji $t$ yang menyatakan memiliki nilai $t_{h i t}>t_{\alpha / 2}(16.592>$ 1.985) dan ( $\operatorname{sig} \alpha=0.000<0.050)$, maka dari penelitian yang dilakukan dalam penelitian terdahulu menyatakan bahwa Promosi memiliki pengaruh positif dan berpengaruh signifikan terhadap Keputusan Pembelian Ulang.

Hasil penelitian ini sejalan dengan penelitan yang dilakukan oleh Bangun dwi prasetio (2016) dengan judul "Pengaruh inovasi produk dan kualitas pelayanan terhadap keputusan pembelian pada batik zhorif di kecamatan danau teluk jambi kota seberang". Hasil dari penelitian ini adalah terdapat pengaruh positif inovasi produk terhadap keputusan pembelian.

Hasil penelitian ini sejalan dengan penelitan yang dilakukan oleh Tamamudin (2012) dengan judul "Analisis pengaruh Pengenalan merek, persepsi Kualitas, harapan konsumen Dan inovasi produk terhadap Keputusan membeli dan dampaknya Pada loyalitas konsumen (studi kasus: produk batik sutra halus merek tamina)" Hasil dari penelitian bahwasanya variabel Inovasi Produk berpengaruh Positif dan secara simultan terhadap Keputusan Pembelian.

4.7.8. Pengaruh Promosi $\left(X_{1}\right)$, Atribut Toko $\left(X_{2}\right)$, dan Inovasi Produk $\left(X_{3}\right)$ Terhadap Keputusan Pembelian Ulang (Y)

Berdasarkan hasil penelitian dan pengolahan data yang dilakukan Pada Nick Coffe di Kota Bengkulu melalui penyebaran kuesioner terhadap 96 orang responden yang telah diuji sehingga dapat diketahui pengaruh Promosi, Atribut 
Toko (Store Attributes), dan Inovasi Produk terhadap Keputusan Pembelian Ulang pada Nick Coffe di Kota Bengkulu.

Promosi $\left(\mathrm{X}_{1}\right)$, Atribut Toko $\left(\mathrm{X}_{2}\right)$, Dan Inovasi Produk $\left(\mathrm{X}_{3}\right)$ memiliki pengaruh terhadap Keputusan Pembelian Ulang (Y), hal ini terlihat pada uji $\mathrm{F}$ yang menyatakan nilai $\mathrm{F}_{\text {hitung }}>\mathrm{F}_{\text {tabel }}$, yaitu $(274.056>3.09)$ dan $(\operatorname{sig} \alpha=0.000$ $<0.050)$ maka dengan demikian dapat disimpulkan bahwa $\mathrm{H}_{4}$ diterima artinya secara bersamaan variable Promosi $\left(\mathrm{X}_{1}\right)$, Atribut Toko $\left(\mathrm{X}_{2}\right)$, dan Inovasi Produk $\left(\mathrm{X}_{3}\right)$ berpengaruh secara signinifikan terhadap Keputusan Pembelian Ulang (Y) pada Nick Coffe di Kota bengkulu.

Hasil penelitian ini sejalan dengan penelitan yang dilakukan oleh Parasian Manurung (2017) dengan judul "Pengaruh Promosi, Harga, Kualitas Pelayanan Terhadap Kepuasan Konsumen dan Keputusan pembelian Ulang di alfamart dan indomaret (studi di alfamart dan indomaret waralaba di jalan ratu dibalau tanjung senang, bandar lampung)" Hasil dari penelitian bahwasanya terdapat pengaruh Promosi, harga, kualitas pelayanan terhadap kepuasan konsumen dan keputusan pembelian ulang berpengaruh signifikan di alfamart dan indomaret jalan ratu dibalau tanjung senang, bandar lampung.

Hasil penelitian ini sejalan dengan penelitan yang dilakukan oleh Silvia Warliana (2013) dengan judul "Pengaruh atribut toko terhadap keputusan Pembelian konsumen pada 999 mini swalayan soekarno hatta Pekan baru" Hasil dari penelitian ini atribut toko berpengaruh positif dengan Kebijakan yang diterapkan oleh 999 mini swalayan terhadap atribut toko yang dapat mempengaruhi keputusan pembelian konsumen. 
Hasil penelitian ini sejalan dengan penelitan yang dilakukan oleh Intan Firdausi (2016) dengan judul "Pengaruh Inovasi Produk, Daya Tarik Ildan dan Persepsi Harga terhadap Keputusan Pembelian pada Cafe dengan Menu Unik (Studi kasus pada Cafe Tombo Ngelak Yogyakarta)" Hasil dari penelitian bahwasanya variabel Inovasi Produk, daya tarik iklan, dan persepsi berpengaruh Positif dan secara simultan terhadap Keputusan Pembelian.

\section{BAB V}

\section{KESIMPULAN DAN SARAN}

\subsection{Kesimpulan}

Berdasarkan hasil penelitian yang telah dilakukan tentang pengaruh Promosi, Atribut Toko (Store Attributes), dan Inovasi Produk terhadap Keputusan Pembelian Ulang pada Nick Coffe di kota Bengkulu, dapat disimpulkan sebagai berikut :

1. Promosi berpengaruh signifikan terhadap Keputusan Pembelian Ulang pada Nick Coffe di Kota Bengkulu.

2. Atribut Toko (Store Atributes) berpengaruh signifikan terhadap Keputusan Pembelian Ulang pada Nick Coffe di Kota Bengkulu.

3. Inovasi Produk berpengaruh signifikan terhadap Keputusan Pembelian Ulang pada Nick Coffe di Kota Bengkulu.

4. Promosi $\left(\mathrm{X}_{1}\right)$, Atribut Toko $\left(\mathrm{X}_{2}\right)$, dan Inovasi Produk $\left(\mathrm{X}_{3}\right)$ secara Bersamaan berpengaruh secara Signifikan terhadap Keputusan Pembelian Ulang (Y) Pada Nick Coffe di Kota Bengkulu. 
5. Berdasarkan nilai koefisien determinasi Adjusted $\left(\mathrm{R}^{2}\right)$ diperoleh nilai sebesar 0.899. Nilai ini mempunyai arti bahwa variabel Promosi, Atribut Toko, dan Inovasi Produk terhadap variabel Keputusan Pembelian Ulang memberikan sumbangan sebesar 0.899 atau $89.9 \%$ terhadap Keputusan Pembelian Ulang pada Nick Coffe di Kota Bengkulu sedangkan sisanya sebesar $10.1 \%$ dipengaruhi oleh variabel lain yang tidak masuk dalam model penelitian ini

\subsection{Saran}

Berdasarkan hasil penelitian, pembahasan dan kesimpulan yang diperoleh, maka saran yang dapat diberikan sebagai berikut :

1. Hasil penelitian menunjukan adanya pengaruh antara variabel Promosi $\left(\mathrm{X}_{1}\right)$ dan Atribut Toko $\left(\mathrm{X}_{2}\right)$, dan Inovasi Produk $\left(\mathrm{X}_{3}\right)$ terhadap Keputusan Pembelian Ulang (Y) Pada Nick Coffe di Kota Bengkulu, variabel Promosi memiliki ratarata terendah yaitu $3.51 \%$. Disarankan untuk lebih baiknya perlu ditingkatkan lagi promosi, seperti perbanyak memberi diskon di saat tertentu ,sering mempromosikan produk di internet, koran, majalah, brosur, dan lain-lain agar dapat meningkatkan Keputusan Pembelian Ulang pada Nick Coffe di kota Bengkulu.

2. Hasil penelitian terlihat bahwa pada variabel Atribut Toko indikator Harga memiliki tanggapan responden yang terendah yaitu $3.52 \%$ dikarenakan harga yang masih lumayan mahal dengan para pesaing. Disarankan sebaiknya harga bisa lebih berfariasi dan memberikan sedikit potongan dengan memberi diskon agar konsumen tertarik untuk melakukan Keputusan Pembelian Ulang. 
3. Hasil penelitian terlihat bahwa pada Inovasi Produk indikator tambahan pada lini produk yang telah ada memiliki tanggapan responden yang terendah yaitu $3.61 \%$ dikarenakan pengusaha kurang melakukan inovasi - inovasi yang mereka pasarkan kepada konsumen, disarankan untuk memberi keragaman menu yang telah ada atau memberi sedikit tampilan baru pada menu - menu lama.

4. Disarankan bagi peneliti selanjutnya khususnya penelitian yang sama perlu dipertimbangkan untuk faktor-faktor lain diluar variabel Promosi, Atribut Toko (Store Attributes), dan Inovasi Produk terhadap Keputusan Pembelian Ulang serta dapat meningkatkan penjualan, sehingga akan menghasilkan penelitian yang lebih baik dan sesuai dengan peningkaatan kualitas penelitian selanjutanya.

\section{DAFTAR PUSTAKA}

Anjani, R. (2019). Tata Kelola Adminitrasi Keuangan, Dan Pembangunan Desa Tepi Laut Kabupaten Bengkulu Utara. Jurnal Pengabdian Masyarakat Bumi Raflesia, 2 (2).

Asmawi, M. (2017). The effect of compensation, empowerment, and job satisfaction on employee loyalty. International Journal of Scientific Research and Management, 5(12), 7590-7599.

Arikunto, Suharsimi. 2006. Prosedur Penelitian Suatu Pendekatan Praktik. Jakarta: Rineka Cipta.

Atchariyachanvanich, K., H. Okada \& N. Sonehara. 2006. "Whatt Keeps Online Customers Repurchasing through the Internet?". ACM S1Gecom Exchanges, Vol. 6, No. 2, December, pp 47-57.

Basu Swastha, 2000, Pengantar Bisnis Modern, Pengantar Ekonomi Perusahaan Modern, Jakarta : Liberty. 
Berman, dan Evan, 2007. Manajemen Ritel. Penerbit Erlangga, Jakarta Kotler dan Amstrong, (2004), Prinsip-prinsip Marketing, Edisi Ketujuh, Penerbit Salemba Empat, Jakarta

Bilson Simamora, 2003, Memenangkan Pasar dengan Pemasaran Efektif \& Profitabel, Gramedia Pustaka Utama, Jakarta.

Boone, Louis E dan Kurtz, David L. (2002). Pengantar Bisnis. Jilid ke-1. Terjemahan Anwar Fadriansyah. Penerbit Erlangga. Jakarta

Chang, T.Z. dan Wildt, A.R., 1994. Price, Product Information, and Purchase Intention: An Empirical Study. Journal of the Academy of Marketing science, 22(1), pp.16-27.

Charles, Noble H.; Sinha, Rajiv K. and Kumar, Ajith. 2002. "Market Orientation and Alternative Strategic Orientations : A Longitudinal Assessment of Performance Implications", Journal of Marketing vol. 66, 25-39

Chen, Honghui, Hoang Hui Nguyen, dan Vijai Singal. 2011. "The Information Content of Stock Split.” Journal of Banking \& Finance 35, no. 9 (September): 2454-2467.

Dwi Wahyu Astuti.2018. "Pengaruh Harga Promosi Terhadap Minat pembelian Ulang Pada Evaluasi Pembeli Starbucks Coffee di Yogyakarta"

Frendy, 2011, Metode Penelitian Untuk Bisnis, Salemba Empat, Jakarta.

Furqon. 1997. Statistika Terapan untuk Penelitian. Bandung: CV Alfabeta

Gatignon, Hubert and Xuereb, JeanMarc, 1997, "Strategic Orientation of the Firm and New Product Performance", Journal of Marketing Research, Vol. 34, February.

Ghozali, Imam.2005, Aplikasi Analisis Multivariate Dengan Program SPSS. Semarang

Ghozali, Imam. 2009. "Aplikasi Analisis Multivariate dengan Program SPSS “. Semarang : UNDIP.

Gujarati, Damodar, 1995. Ekonometrika Dasar. Penerbit Erlangga, Jakarta

Hadari Nawawi. 1991. Metode Penelitian Bidang Sosial. Yogyakarta: UGM Press. 
Hellier, P. K., G. M. Geursen, R. A. Carr \& J. A. Rickard. 2003. "Customer Repurchase Intention: A general structural equation model". European Journal of Marketing, Vol. 37, No. 11/12, pp.1762-1800.

Hult, G. 1998. Managing the International Strategic Sourcing Process as a Market-Driven Organizational Learning System. Decision Sciences, 29(1): 193-216

Intan firdausi .2016. “ Pengaruh Inovasi Produk, Daya Tarik Ildan dan Persepsi Harga terhadap Keputusan Pembelian pada Cafe dengan Menu Unik (Studi kasus pada Cafe Tombo Ngelak Yogyakarta)". Skripsi, Fakultas Ekonomi Universitas Negri Yogyakarta

Intan Mawarsari.2018. "Pengaruh kualitas produk, harga, dan promosi terhadap minat beli ulang konsumen olahan buah carica di daerah Wonosobo". Skripsi,Fakultas Ekonomi Universitas sanata darma Yogyakarta

Johanna P., Myra, 2006. Analisis Faktor-Faktor Yang Mempengaruhi Minat Beli Ulang (Studi Kasus Konsumen pada Mandala Airline - Semarang). Program Studi Magister Manajemen Program Pasca Sarjana Universitas Diponegoro, Semarang.

Kotler dan Keller, 2007. Manajemen Pemasaran, Edisi 12, Jilid 1, PT.Indeks, Jakarta.

Kotler, Philip. 2007.Prinsip-Prinsip Pemasaran. Jakarta: Erlangga.

Kusmono, Gugup, Pengantar Bisnis, Edisi I, Cetakan I, BPFE, Yogyakarta, 2011

Lindquist, Jack. "Political linkage- The Academic Innovation Process". The Journal of Higher Education. 1974. No. 5: 323-343. http://www.jstor.org/stable/1980380 (diakses Mei 20, 2013).

Long-Yi Lin and Yeun-Wen Chen. 2009. A Study on the Purchase Intentions on Repurchase Decisions : the Moderating Effects of Reference Groups and Perceived Risks. Journal of Tourism Review (Online), Vol. 64, No. 3, pp. 28-48, (http://www.emeraldinsight.com, diakses 12 Maret 2012).

Lukas, Bryan. A and Ferrell, O. C, 2000, The Effect of Market Orientation on Product Innovation, Journal of the Academy of Marketing Science, Vol. 28, Spring.

Madura, J. (2001). Pengantar Bisnis. Jilid Kedua. Jakarta: Erlangga. 
Melisa,Yuda (2012). "Pengaruh Bauran Pemasaran Ritel Terhdap Keputusan Pembelian Ulang Konsumen Mega Prima Swalayan Payakumbuh". Management Jurnal 1, (1), 2-3.

Milton R.J. Salton dan Kwang-Shin Kim, 2001. Structur of Bacteria. . www.bact.wisc.edu. Departement of Baceriology University of WisconsinMadison.USA

Mowen, J.C, Minor.M. (1998). Consumer Behavior. New York : Prentice Hall Inc Kotler, Amstrong. 2001. Prinsip-prinsip pemasaran, Edisi keduabelas, Jilid 1. Jakarta: Erlangga

Muhyidin.2017. "Pengaruh atribut toko terhadap keputusan pembelian barang di toko ritel (studi khasus pada toko basmalah pada cabang rembang kabupaten pasuruan jawa timur)" Skripsi,Fakultas Ekonomi Universitas Islam Negeri mualan Malik Ibrahim, Malang.

Nata Wirawan, (2002), Cara Mudah Memahami Statistik 2, Edisi Kedua,Keraras Emas,Denpasar.

Novantiano.(2007). Analisa Faktor-Faktor yang Mempengaruhi Keputusan Pembelian Ulang Barang-Barang Elektronik Buatan RRCdi Toko Hartono Elektronika.From:http://digilib.petra.ac.id/

Onsardi, O. (2018). Loyalitas Karyawan pada Universitas Swasta di Kota Bengkulu. COSTING: Journal of Economic, Bussines and Accounting, 2(1), 1-13.

Onsardi, O. (2019). Pengaruh Kompensasi Dan Pemberdayaan, Terhadap Loyalitas Karyawan Dengan Variabel Intervening Kepuasan Kerja (No. jsypg). Center for Open Science.

Petrick, J.F., S.J. Backman, dan R.D. Bixler. 1999. An investigation of selected factors' impact on golfer satisfaction and perceived value. Journal of Park and Recreation Administration, 17 (1):40-59

Prakosa, Bagas, 2005, "Pengaruh Orientasi Pasar, Inovasi Dan Orientasi Pembelajaran Terhadap Kinerja Perusahaan Untuk Mencapai Keunggulan Bersaing (Studi Empiris Pada Industri Manufaktur Di Semarang)", Journal Studi Manajemen \& Organisasi, Vol. 2 No.1

Silvia, Esther.G.,(2009), “Atribut Konsumen dan Minat Pembelian Ulang : Studi Pada Waroeng Spesial Sambal Temanggung”,Skripsi,Fakultas Ekonomi Universitas Atma Jaya Yogyakarta.(tidak dipublikasikan). 
Silvia Warliana.2013. "Pengaruh atribut toko terhadap keputusan Pembelian konsumen pada 999 mini swalayan soekarno hatta Pekan baru".

Skripsi,Fakultas Ekonomi Universitas Islam Negeri Sultan Syarif Kasim, Riau.

Sousa, F.C.; Pellissier, R; dan Monteiro,I.P. 2012. Creativity, Innovation And Collaborative Organizations. The International Journal of Organization Innovation Vol 5 Num 1.p.26-59

Spais, G. S. \& K. Vasileiou. 2006. "Path Modeling The Antecedent Factors To Consumer Repurchase Intentions For Advanced Technological Food Products: Some Correlations Between Selected Factor Variables”. Journal of Business Case Studies, Vol. 2, No. 2, Second Quarter.

Sumarwan, Ujang. 2002. Perilaku Konsumen: Teori dan Penerapannya dalam Pemasaran. Bogor: Ghalia Indonesia

Sugiyono. 2012. Metode Penelitian Kuantitatif, Kualitatif dan R\&D. Bandung Alfabeta.

Sugiyono. 2007. Metode Penelitian Kuantitatif Kualitatif dan R\&D. Bandung: Alfabeta.

Sugiyono. 2008. Metode Penelitian Kuantitatif Kualitatif dan R\&D. Bandung : ALFABETA

Sugiyono. 2013. Metode Penelitian Pendidikan Pendekatan Kuantitatif, Kualitatif, dan R\&D. Bandung: Alfabeta.

Suliyanto, 2005, Analisis Data dalam Aplikasi Pemasaran, Bogor: Ghalia Indonesia.

Suryana. (2001). Kewirausahaan. Jakarta: Salemba Empat.

Sutrisno Hadi. (2002). Metodologi Riset. Yogyakarta: Andi Ofset

Sya'roni, D.A.W. dan Sudirham, J.J. 2012. Kreativitas dan Inovasi Penentu Kompetensi Pelaku Usaha Kecil. Jurnal Manajemen Teknologi, Fakultas Pascasarjana Universitas Komputer Indonesia (UNIKOM). Volme 11 No.1.

Sylvi, Yohana.P.A.,(2009), "Pengaruh Perceived Quality, Perceived Value, Brand Preference, Consumer Satisfaction, dan Consumer Loyalty pada Repurchase Intention".Skripsi,Fakultas Ekonomi Universitas Sebelas Maret Surakarta. 
Tamamudin. (2012). “Analisis Pengaruh Pengenalan Merek, Persepsi Kualitas, Harapan Konsumen dan Inovasi Produk terhadap Keputusan Membeli Dan Dampaknya Pada Loyalitas Konsumen”. Jurnal Penelitian Vol. 9, No. 2, November 2012. Hlm. 283-300

Tjiptono. 2001. Manajemen Pemasaran dan Analisa Perilaku Konsumen, Yogyakarta: BPFE.

Wahyu Ika Purnamasari .2015. “ Analisis Pengaruh Promosi dan Kepuasan Konsumen Terhadap Keputusan Pembelian Ulang (Studi Kasus di Miulan Hijab Semarang”. Universitas Islam Walisongo, Semarang”.

Skripsi,Fakultas Ekonomi Universitas Islam Indonesia, Yogyakarta.

Woodruff, Robert B. (1997). Customer Value : The Next Source for Competitive Advantage, Journal of the Academy of Marketing Science, Vol. 25, No. 2, 139 - 153 . 